
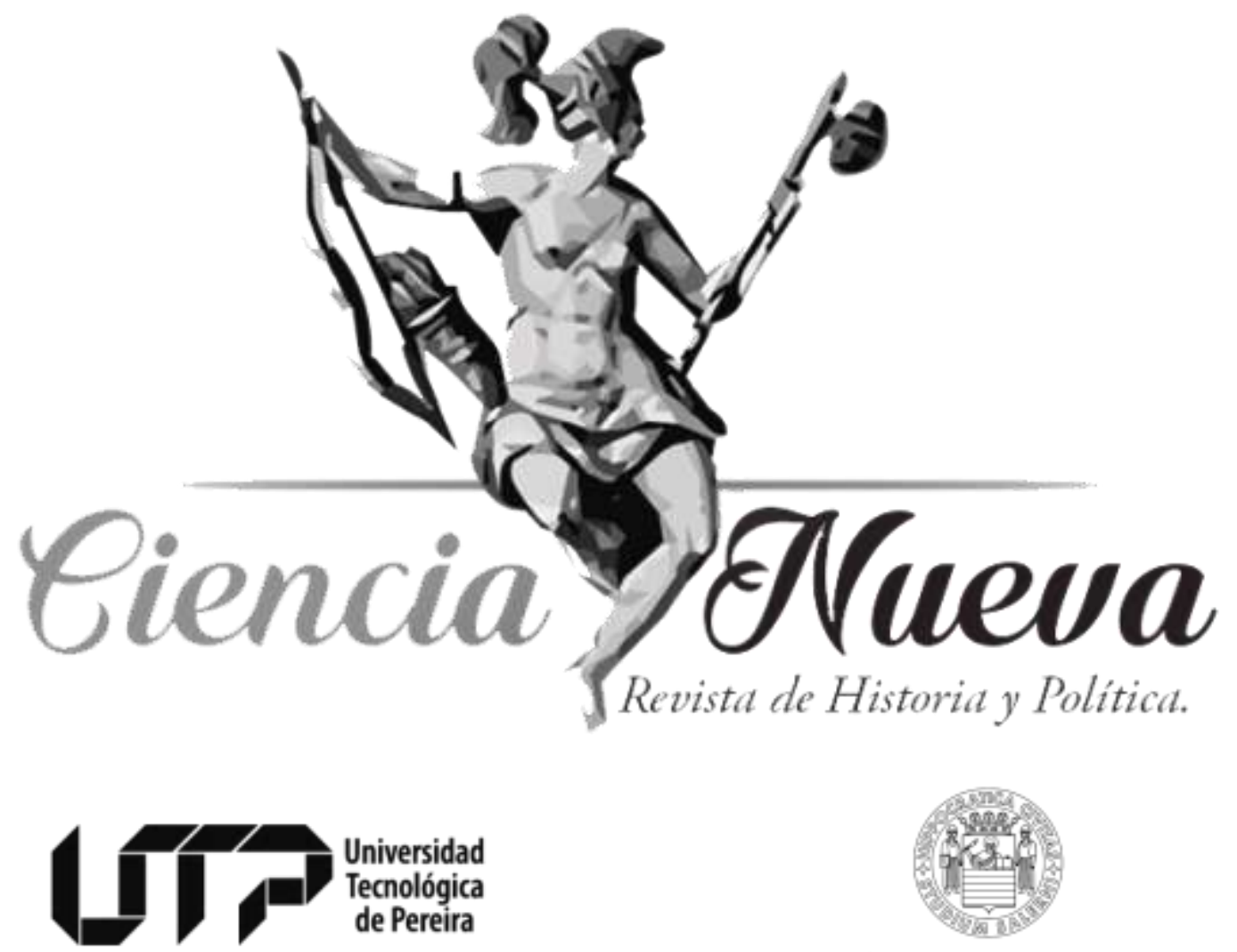

UNIVERSITÀ DEGLI STUDI DI SALERNO

Maestría en Historia

Maestría en Ciencia Política

ANALES Y MEMORIAS DEL CENTRO-OCCIDENTE COLOMBIANO

LAS DOS ANSERMAS. SEGUIMIENTO DOCUMENTAL AL TRASLADO DE UNA POBLACIÓN

THE TWO ANSERMA. DOCUMENTARY RESEARCH ABOUT THE RELOCATION OF A POPULATION DOI: https://doi.org/10.22517/25392662.23221 Juan Carlos Vallejo Velásquez pp. 192-224

Vol. 3 Núm. 2 | Julio-Diciembre de 2019 Pereira, Colombia 


\title{
LAS DOS ANSERMAS. SEGUIMIENTO DOCUMENTAL AL TRASLADO DE UNA POBLACIÓN*
}

\section{THE TWO ANSERMA. DOCUMENTARY RESEARCH ABOUT THE RELOCATION OF A POPULATION}

\author{
Juan Carlos Vallejo Velásquez.** \\ juanc1663@gmail.com
}

ORCID: http://orcid.org/0000-0002-3807-4625

$\begin{aligned} \text { Recibido: } & 27 \text { de octubre de } 2018 . \\ \text { Revisado: } & \text { 06 de mayo de } 2019 . \\ \text { Aceptado: } & \text { 05 de diciembre de } 2019 . \\ \text { Publicado: } & 30 \text { de diciembre de } 2019 .\end{aligned}$

$\mathbf{J}$

orge Robledo funda la ciudad de Santana (San Juan) y la iglesia Mayor Santa María de los Caballeros en cierta sabana en una Provincia que los indios llaman Guarma. Con el aditamento de poderla trasladar si se encontraba un mejor lugar, lo cual sucede casi de manera inmediata, pues la primera fundación la hace más para hacerse a la tierra por la presión de los conquistadores que venían de Cartagena tras Juan Vadillo. La primera ubicación se cree que es un sitio cercano a Belén de Umbría y la segunda en el Cerro de Anserma.

El aditamento del que se hace mención es un poderoso elemento que luego es utilizado (hipótesis mía) para la traslación en 1717 a un sitio que estaba incluido en los límites de la ciudad y que se llamaba Las Lajas.

La ciudad se funda con el nombre de Santana; luego, se cambia por San Juan y finalmente, Anserma. Último nombre verdaderamente autóctono derivado de Anser, sal para los indios, aunque la provincia en general se llama Humbra.

\footnotetext{
* Este documento respeta las directrices y normas dispuestas en la Declaración de Ética de Publicación de Ciencia Nueva, Revista de Historia y Política. Esta declaración puede consultarse en la página web de la revista: http://revistas.utp.edu.co/index.php/historia

${ }^{* *}$ Licenciado en Ciencias Sociales por la Universidad Tecnológica de Pereira y magíster en Enseñanza de las Ciencias Exactas y Naturales por la Universidad Nacional de Colombia, Sede Manizales. Rector de la Institución Educativa Ocuzca de Anserma, Caldas.
} 


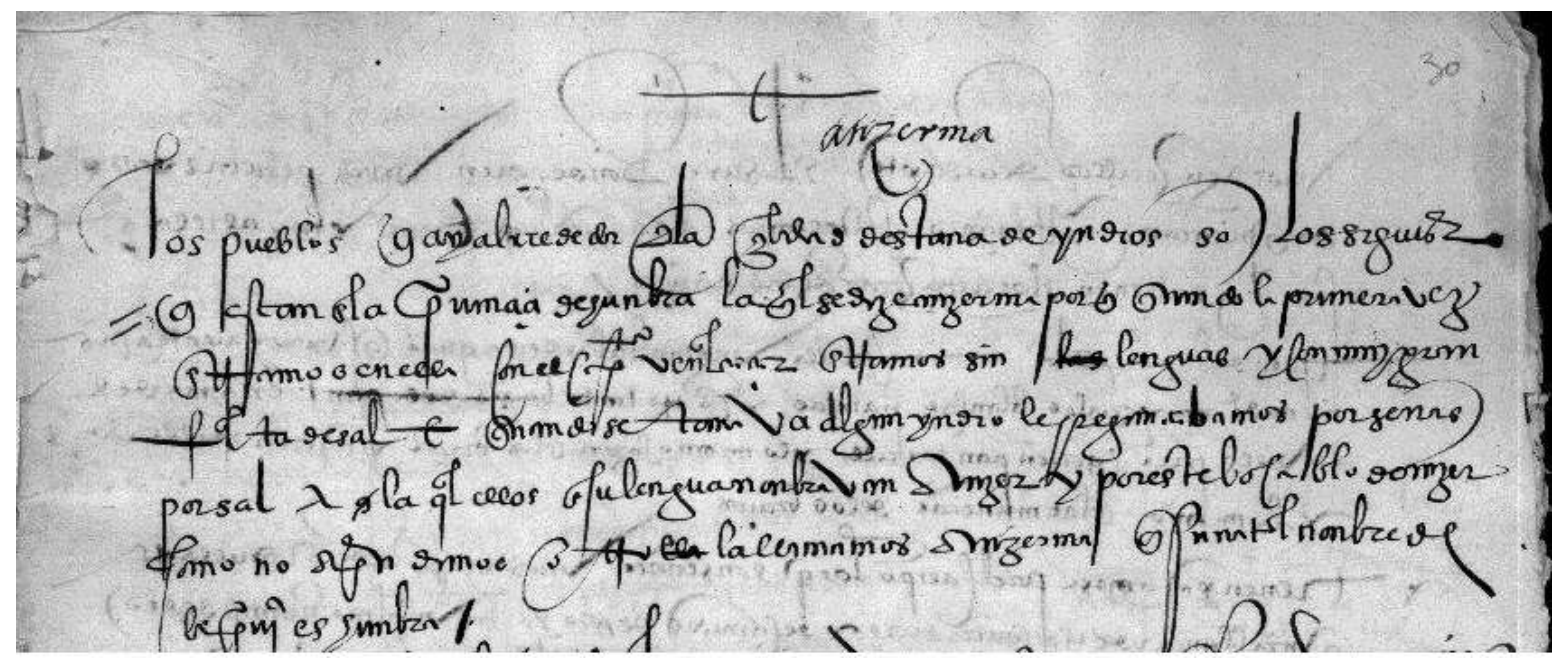

Figura 1. Anser-Sal. Provincia Humbra

Fuente: Archivo General de Indias (AGI), España. PATRONATO,28,R.66 en " Relación del viaje de Jorge Robledo a Quimbaya, Antioquia, etc.", Ministerio de Cultura y Deporte. Gobierno de España, acceso el 15 de noviembre de 2019, http://pares.mcu.es/ParesBusquedas20/catalogo/show/122042.

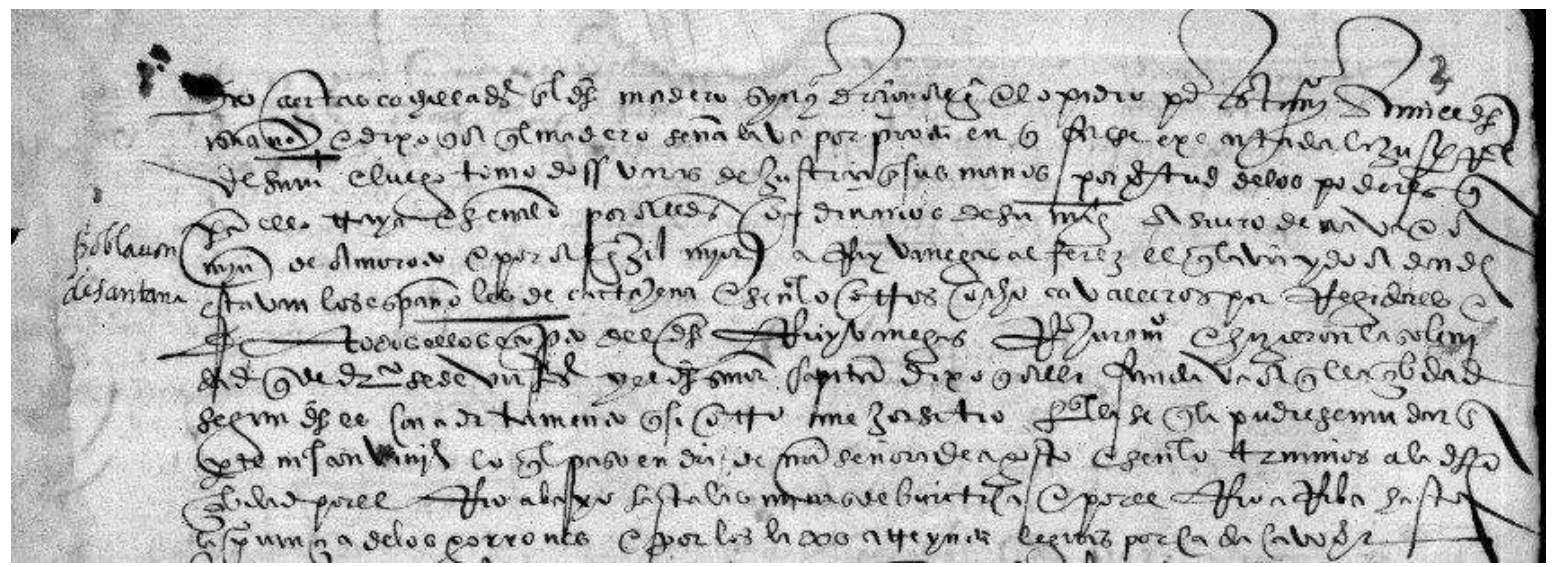

Figura 2. Fundación de Santana en la Provincia de Anserma. Francisco Pizarro

Fuente: Archivo General de Indias (AGI), España. PATRONATO,28,R.66 en "Relación del viaje de Jorge Robledo a Quimbaya, Antioquia, etc.", Ministerio de Cultura y Deporte. Gobierno de España, acceso el 15 de noviembre de 2019, http://pares.mcu.es/ParesBusquedas20/catalogo/show/122042. 


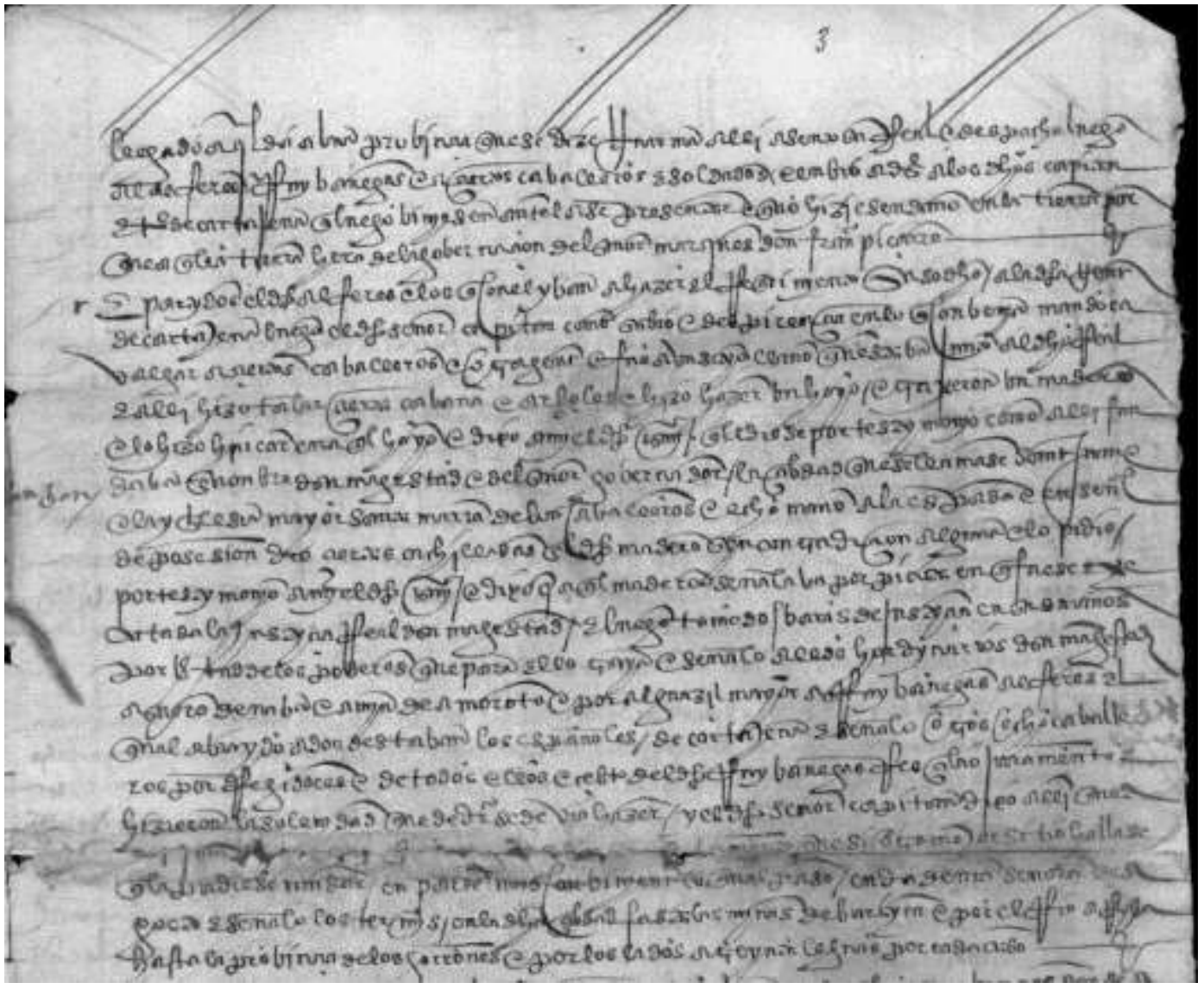

Figura 3. Fundación de San Juan en la Provincia de Anserma. Pascual de Andagoya

Fuente: Archivo General de Indias (AGI), España. PATRONATO,185,R.19 en "Viaje del capitán Jorge Robledo: Ancerma, Quimbaya y Cartago", Ministerio de Cultura y Deporte. Gobierno de España, acceso el 15 de noviembre de 2019, http://pares.mcu.es/ParesBusquedas20/catalogo/show/125291.

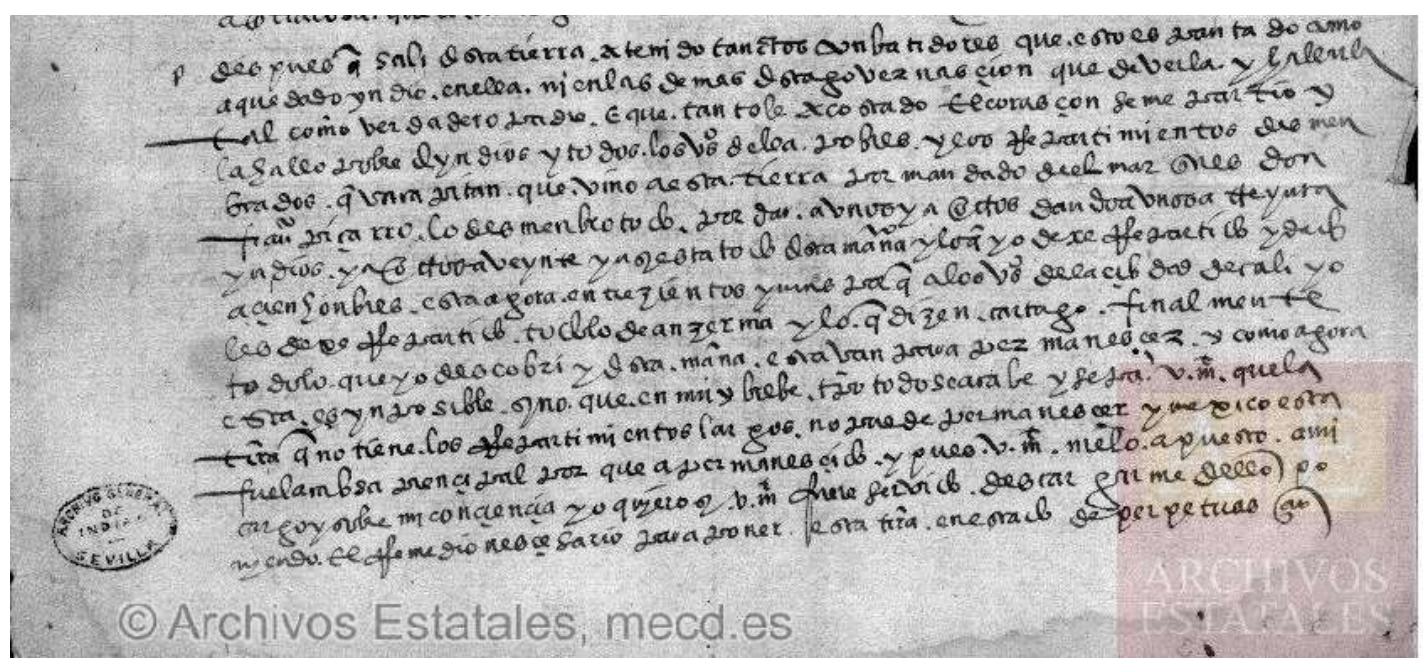

Figura 4. Anserma

Fuente: Archivo General de Indias (AGI), España. PATRONATO, 192, N. 1, R 27 (2) en "Informaciones de Sebastián de Belalcázar", Ministerio de Cultura y Deporte. Gobierno de España, acceso el 15 de noviembre de 2019, http://pares.mcu.es/ParesBusquedas20/catalogo/description/393190?nm. 
La ciudad tiene un extenso territorio que es entregado a los peninsulares en las encomiendas y empieza a figurar en los primeros mapas y planos.

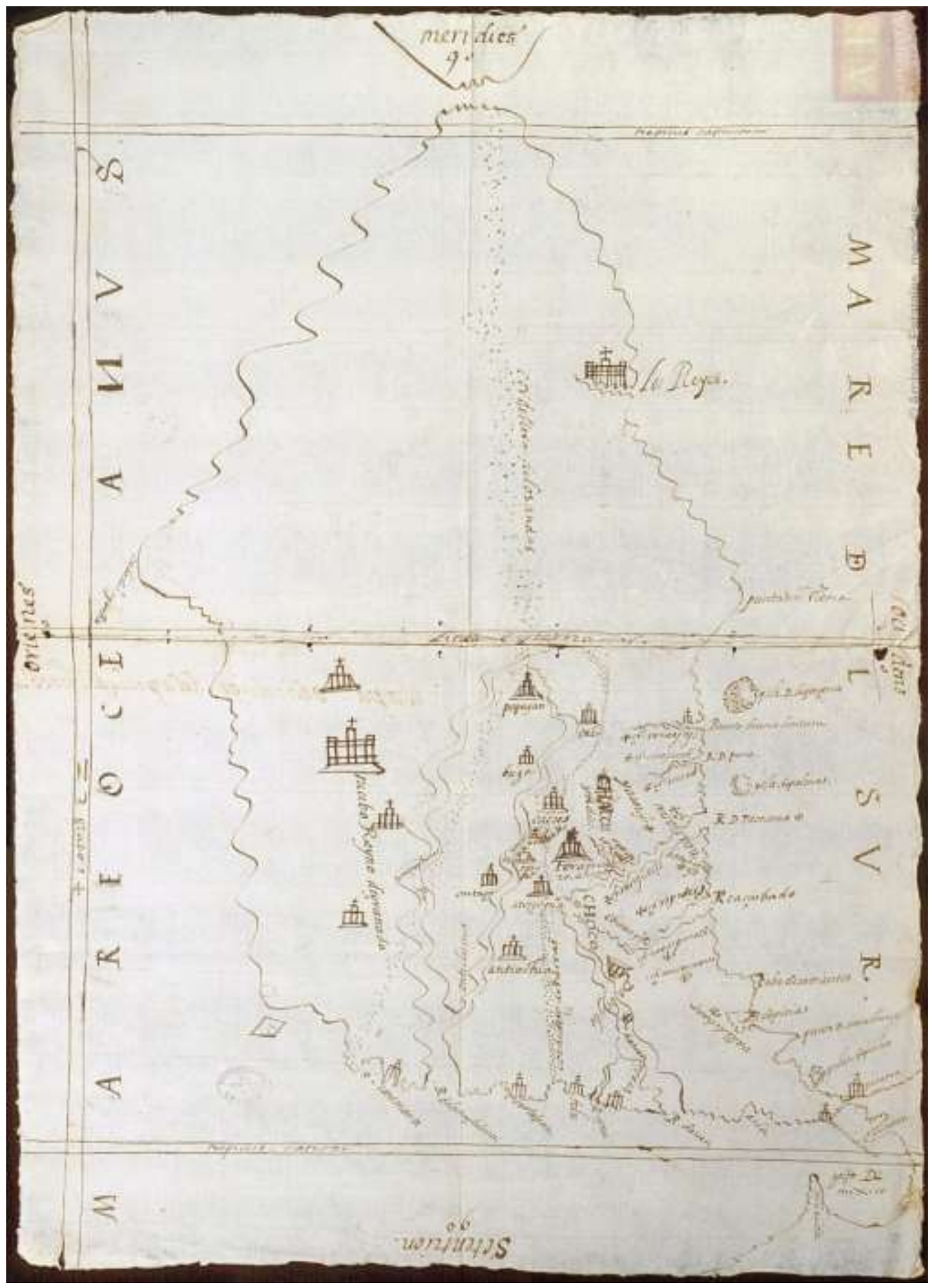

Figura 5. Provincia del Chocó, 1597

Fuente: Archivo General de Indias (AGI), España. MP-PANAMA,329 en "Mapa o descriçión de la Provincia del Chocó", Ministerio de Cultura y Deporte. Gobierno de España, acceso el 15 de noviembre de 2019, http://pares.mcu.es/ParesBusquedas20/catalogo/description/22401. 


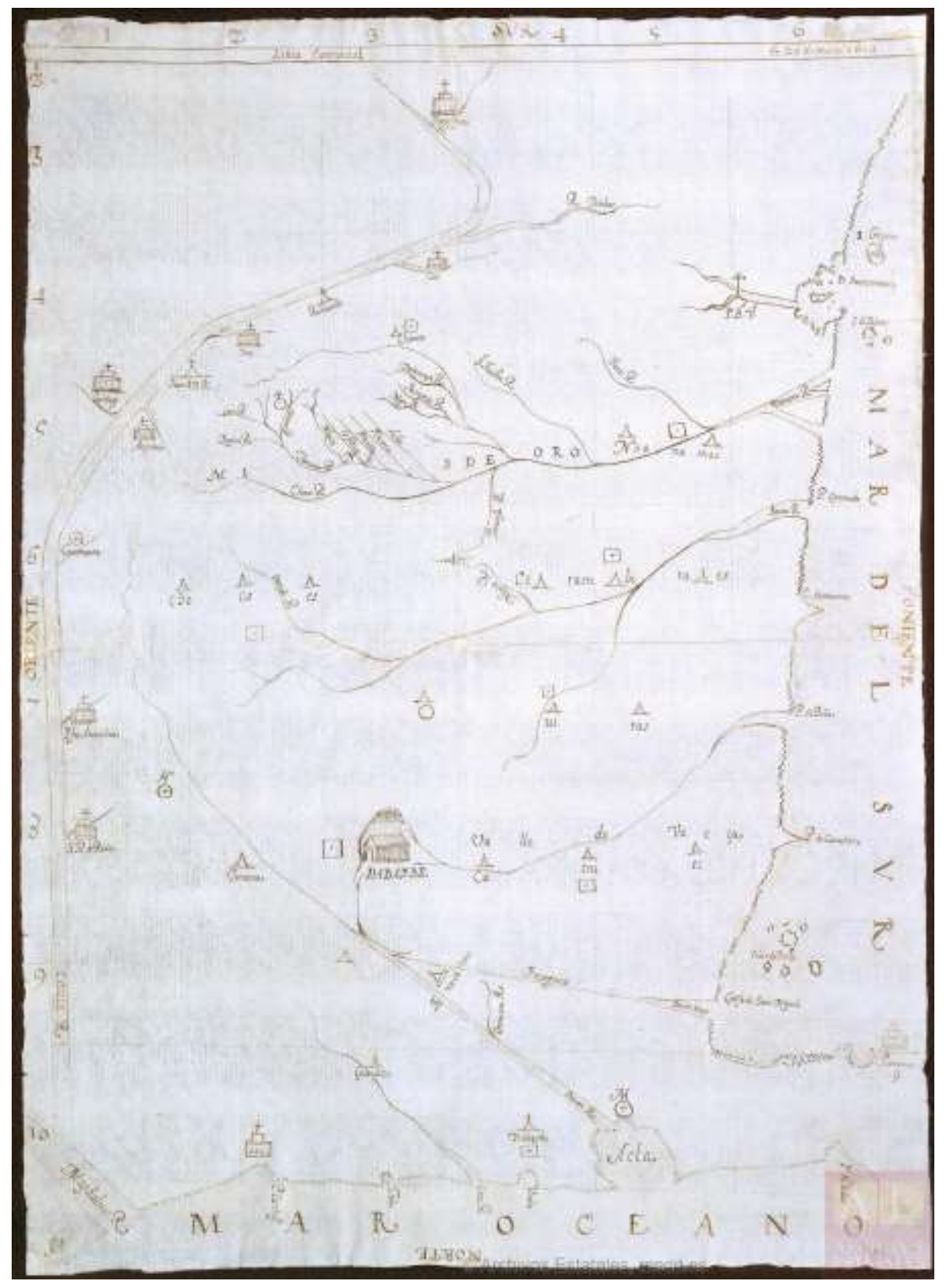

Figura 6. Provincia del Chocó, 1610

Fuente: Archivo General de Indias (AGI), España. MP-PANAMA,29 en "Mapa de la provincia del Chocó", Ministerio de Cultura y Deporte. Gobierno de España, acceso el 15 de noviembre de 2019, http://pares.mcu.es/ParesBusquedas20/catalogo/description/22061. 


\begin{tabular}{|l|l|}
\hline Archivo & Archivo General de la Nación de Colombia \\
\hline Sección & Seoción Mapas y Planos \\
\hline Nivel & Fondo \\
\hline Titulo y Signatura & Mapoteca-SMP4-MAPOTECA:SMP4.4 \\
\hline Fecha inicial y techa final & {$[S / F]$ - } \\
\hline
\end{tabular}

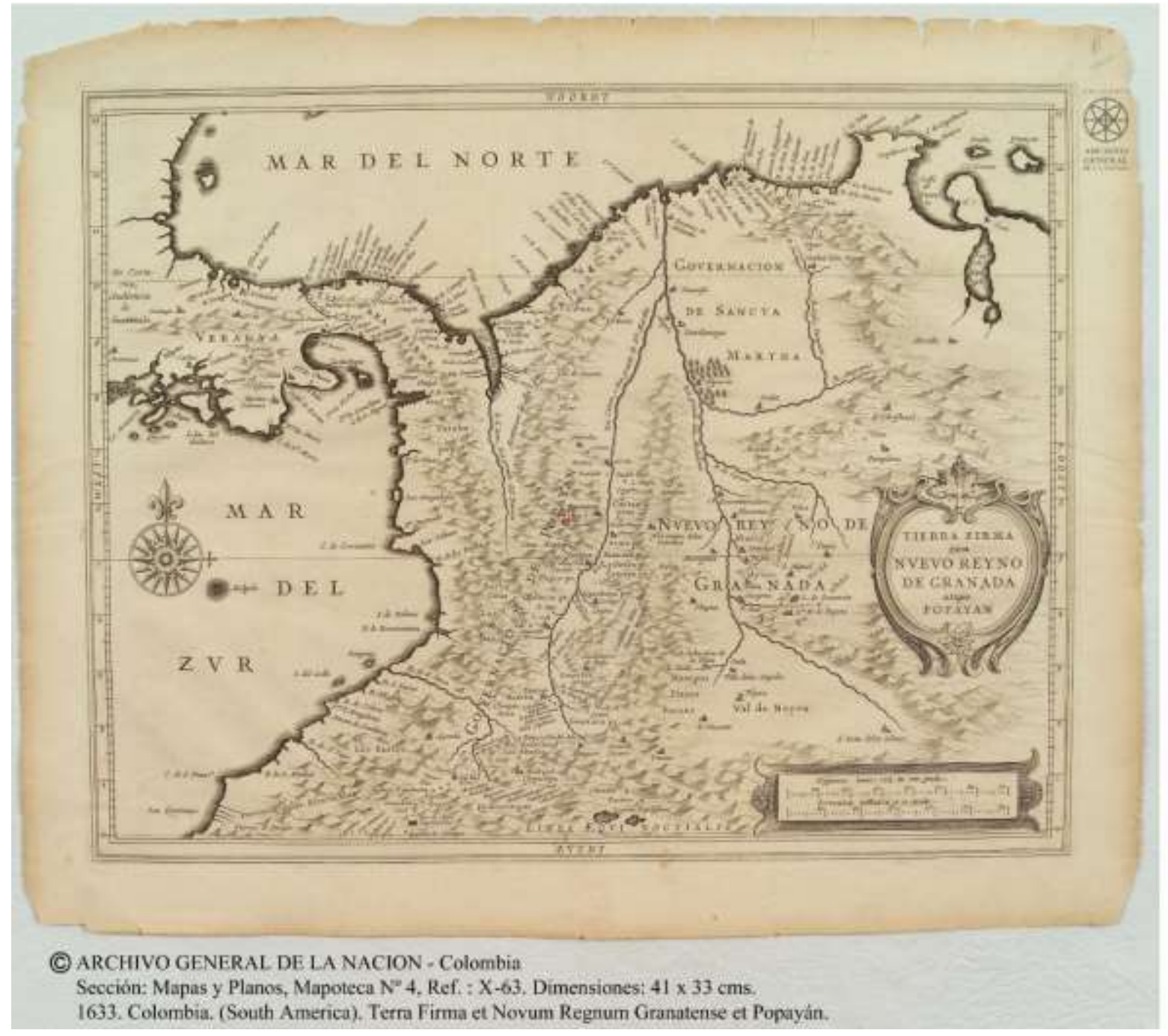

Figura 7. Mapa de la Nueva Granada, 1633

Fuente: Archivo General de la Nación (AGN), Popayán, Sección Mapas y Planos, Mapoteca SMP.4, acceso el 15 de noviembre de 2019,

http://consulta.archivogeneral.gov.co/ConsultaWeb/imagenes.jsp?id=3255709\&idNodoImagen=3255710\&tot al $=1 \&$ ini $=1 \&$ fin $=1$

El centro urbano de Anserma guardaba las características de las fundaciones españolas. Se construía la iglesia y a su alrededor las demás dependencias administrativas como la casa del cabildo, la cárcel, el comercio y demás; a partir de allí, se irradiaba la población que tomaba los solares y construía las casas con el material disponible. En el caso 
de Anserma se hicieron con madera, guadua y paja, implicando con ello la inexistencia de vestigios coloniales. Las actividades económicas giraban alrededor de la agricultura, pero la más importante fue la minería del oro, focalizada en Supía y las minas del río Cauca y Marmato. También se destacó la explotación de la sal y la ganadería, esta última en los llanos de Supía y al sur del territorio, cerca de Cartago, trasladada de su antiguo asiento en 1691.

El poblado original de Anserma tenía su dinámica de funcionamiento en las labores administrativas y religiosas; sin embargo, su crecimiento poblacional se dirigió a las zonas con marcado interés económico para sus pobladores, las zonas de minería. El casco urbano era ocupado por los encomenderos y sus familias, como parte de su obligación. Los religiosos tomaron como centro de operaciones el Convento de San Francisco para irradiar la religión a todos los pueblos de indios y las autoridades civiles y militares.

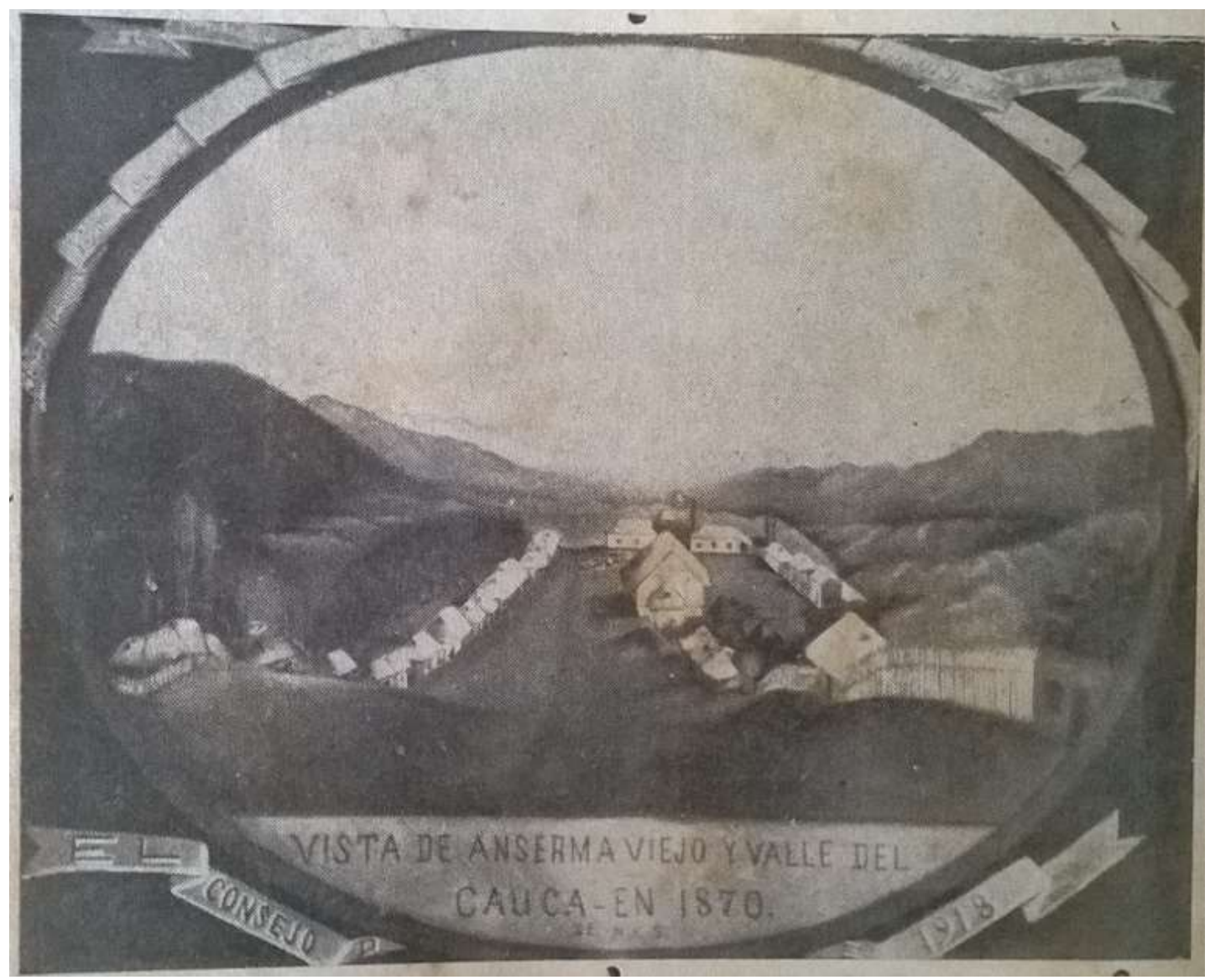

Figura 8. Distribución del pueblo

Fuente: Arturo Restrepo G y Roberto. Anserma 1539 - 1957. Bajo los auspicios del Pbro. César Agudelo O. Imprenta Departamental - Manizales, p. 140.

El Sitio de "Las Lajas" fue el escogido para hacer la mudanza de Anserma. La fundación de Cartago como resultado del establecimiento de explotaciones ganaderas, muchos años antes del traslado oficial en 1691, animó a muchos de los moradores de Anserma a establecer posadas y ganaderías en la misma época. Prueba de esto es el siguiente documento, donde además de un extenso prontuario de motines en Anserma, aporta datos de los sitios y rutas que se tomaban para llegar de Cartago y Sitio de las Lajas hasta Anserma. 


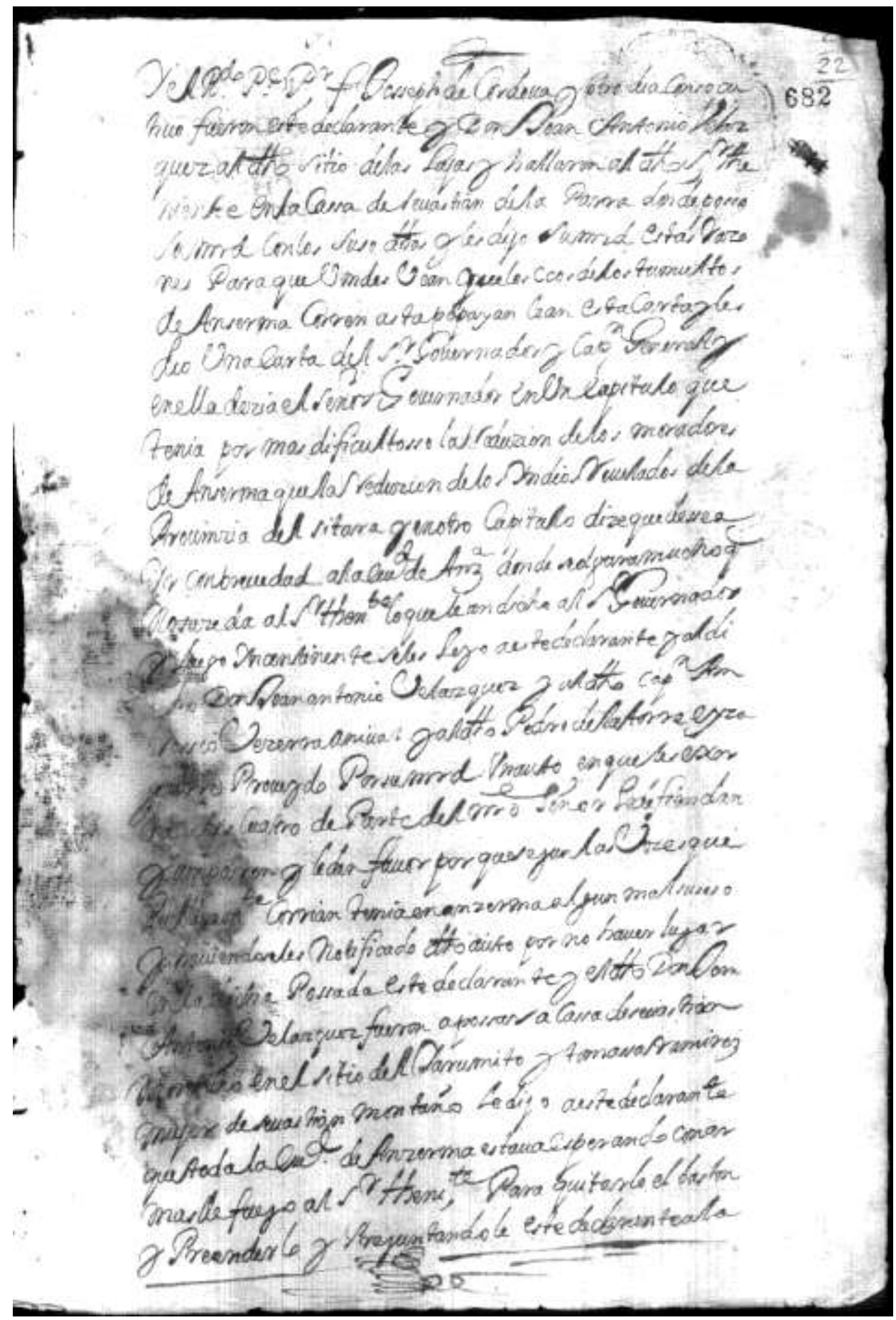

Figura 9. Joaquín de Verois y Cabildo Anserma, 1686

Fuente: Archivo General de la Nación (AGN), Historia Civil: SC.29, 1, D.14, acceso el 15 de noviembre de 2019 ,

http://consulta.archivogeneral.gov.co/ConsultaWeb/imagenes.jsp?id=3052699\&idNodoImagen=2703593\&tot $\mathrm{al}=618 \&$ ini $=1 \&$ fin $=20$ 
1. El Reverendo Padre Fray Joseph de Córdoba y otro día consecu-

2. tivo fueron este declarante y Don Juan Antonio Velás-

3. quez al dicho Sitio de Las Lajas y hallaron al dicho Señor Te-

4. nente en la casa de Sebastián de la Parra donde posó

5. su merced con los suso dichos y les dijo su merced estas razo-

6. nes para que Vuestras Mercedes vean que los ecos de los tumultos

7. de Anserma corren hasta Popayán lean esta carta y les

8. dio una carta del Señor Gobernador y Capitán General y

9. en ella decía el Señor Gobernador en un capítulo que

10. tenía por más dificultoso la reducción de los moradores

11. de Anserma que la reducción de los indios rebelados de la

12. Provincia del Citará y en otro capítulo dice que desea

13. ir con brevedad a la Ciudad de Anserma donde se holgará mucho que

14. no suceda al Señor Teniente lo que le han dicho al Señor Gobernador

15. y luego incontinente se les leyó a este declarante y al di-

16. cho Don Juan Antonio Velásquez y al dicho Capitán Am-

17. brosio Becerra Aníbal y al dicho Pedro de la Torre e Iza-

18. guirre proveído por su merced un auto en que les exor-

19. ta a los cuatro de parte de su merced Señor le defiendan

20. y amparen y le den favor porque según las voces que

21. públicamente corrían temía en Anserma algún mal suceso

22. y habiéndoseles notificado dicho auto por no haber lugar

23. en la dicha posada este declarante y el dicho Don Juan

24. Antonio Velásquez fueron a posar a casa de Sebastián

25. Montaño en el Sitio del Yarumito y Tomasa Ramírez

26. mujer de Sebastián Montaño le dijo a este declarante

27. que toda la Ciudad de Anserma estaba esperando con ar-

28. mas de fuego al Señor Teniente para quitarle el bastón

29. y prenderlo y preguntándole este declarante a la 


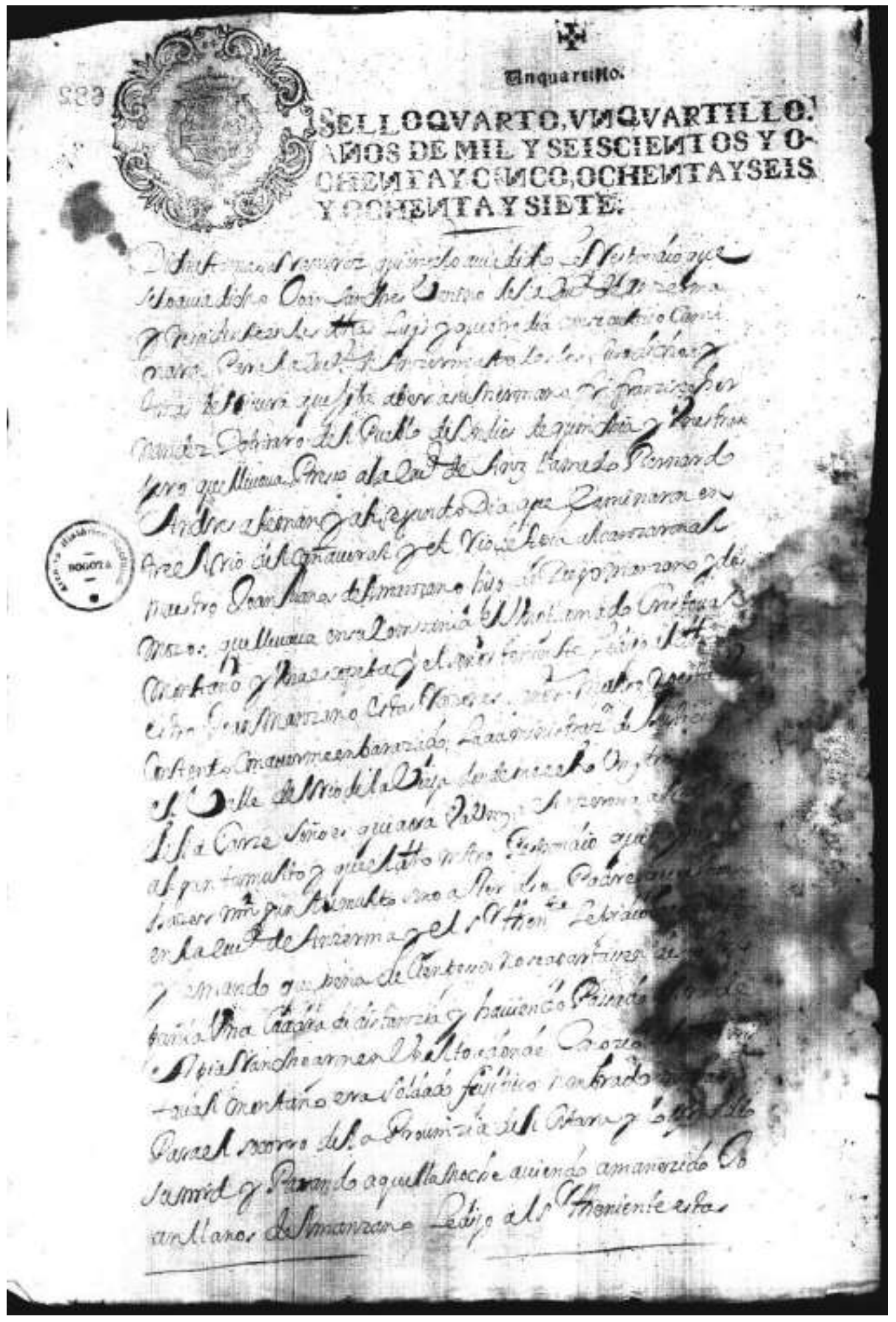

Figura 10. Joaquín de Verois y Cabildo Anserma, 1686.

Fuente: Archivo General de la Nación (AGN), Historia Civil: SC.29, 1, D.14, acceso el 15 de noviembre de 2019 ,

http://consulta.archivogeneral.gov.co/ConsultaWeb/imagenes.jsp?id=3052699\&idNodoImagen=2703593\&tot $\mathrm{al}=618 \&$ ini $=1 \&$ fin $=20$ 
1. Dicha Tomasa Ramírez quien se lo había dicho le respondió que

2. se lo había dicho Juan Sánchez vecino de la Ciudad de Anserma

3. y residente en las dichas Lajas y que otro día consecutivo cami-

4. naron para la Ciudad de Anserma todos los suso dichos y

5. Tomás de Rivera que iba a ver a su hermano Fray Francisco Her-

6. nández Doctrinero del Pueblo de indios de Quinchía y un extran-

7. jero que llevaba preso a la Ciudad de Anserma llamado Bernardo

8. Andrés alemán y al segundo día que caminaron en

9. tre el río del Cañaveral y el río de Apía alcanzaron al

10. Maestro Juan Llanos del Manzano hijo de Diego Manzano y dos

11. mozos que llevaba en su compañía el uno llamado Cristóbal

12. Montaño y una escopeta y el Señor Teniente le dijo al dicho Ma-

13. estro Juan Manzano estas razones = no está Vuestra Merced

14. contento con haberme embarazado la administración de justicia en

15. El Valle del río de la Vieja donde me echó un (ilegible)

16. (ilegible) sino es que ahora va a venir a Anserma a hacer

17. algún tumulto y el que el dicho Maestro respondió que no iba a

18. hacer ningún tumulto sino a ver a su padre que estaba

19. en la Ciudad de Anserma y el Señor Teniente le pidió las (ilegible)

20. y le mandó que pena de cien pesos no se apartasen de su com-

21. pañía una cuadra de distancia y habiendo pasado el río de

22. Apía ranchearon en un alto a donde conoció al dicho Cris-

23. tobal Montaño era soldado fugitivo nombrado por Sargento

24. para el socorro de la Provincia del Citará y lo prendió

25. su merced y pasando aquella noche habiendo amanecido Ju-

26. an Llanos del Manzano le dijo al Señor Teniente estas 


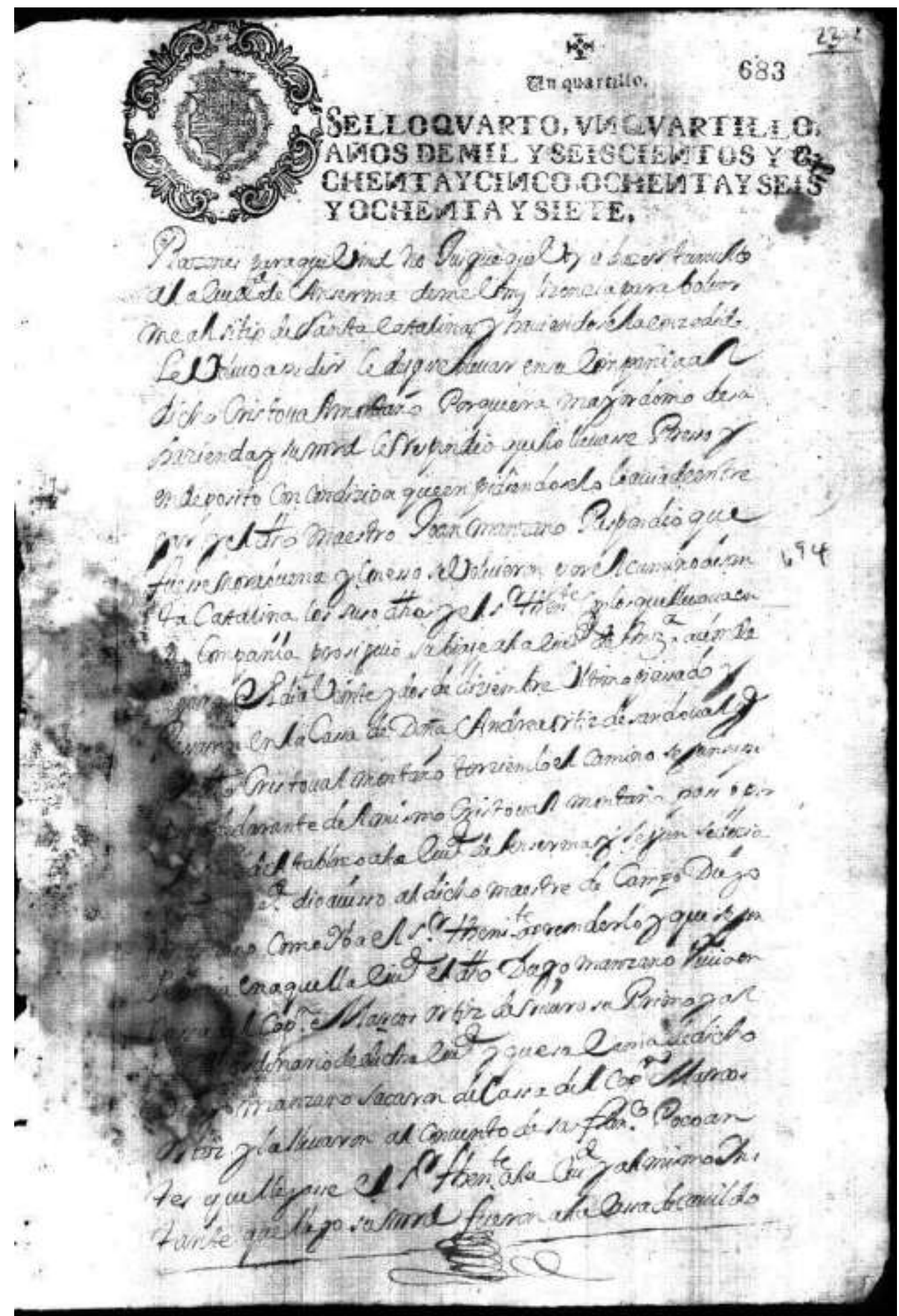

Figura 11. Joaquín de Verois y Cabildo Anserma, 1686

Fuente: Archivo General de la Nación (AGN), Historia Civil: SC.29, 1, D.14, acceso el 15 de noviembre de 2019 ,

http://consulta.archivogeneral.gov.co/ConsultaWeb/imagenes.jsp?id=3052699\&idNodoImagen=2703593\&tot $\mathrm{al}=618 \&$ ini $=1 \&$ fin $=20$ 
1. Razones para que Vuestra Merced no juzgue que voy a hacer tumulto

2. a la Ciudad de Anserma deme vuestra merced licencia para volver-

3. me al Sitio de Santa Catalina y habiéndosela concedido

4. le volvió a pedir le dejase llevar en su compañía al

5. dicho Cristóbal Montaño porque era mayordomo de su

6. hacienda y su merced le respondió que lo llevase preso y

7. en depósito con condición que en pidiéndoselo lo había de entre-

8. gar y el dicho Maestro Juan Manzano respondió que

9. fuese en hora buena y con eso se volvieron por el camino de San-

10. ta Catalina los suso dichos y el Señor Teniente con los que llevaba en

11. su compañía prosiguió su viaje a la Ciudad de Anserma a donde

12. llegaron el día veinte y dos de diciembre último pasado y

13. posaron en la casa de Doña Andrea Ortiz de Sandoval y

14. el dicho Cristóbal Montaño torciendo el camino según supo

15. este declarante del mismo Cristóbal Montaño pasó por

16. el Sitio del Tablazo a la Ciudad de Anserma y según se decía

17. en dicha ciudad dio aviso al dicho maestre de Campo Diego

18. Manzano como iba el Señor Teniente a prenderlo y que según

19. se decía en aquella ciudad el dicho Diego Manzano vivía en

20. casa del Capitán Marcos Ortiz de Rivero su primo y al-

21. calde ordinario de la dicha ciudad y que su cama de dicho

22. Diego Manzano sacaron de casa del Capitán Marcos

23. Ortiz y la llevaron al Convento de San Francisco poco an-

24. tes que llegase el Señor Teniente a la ciudad y al mismo ins-

25. tante que llegó Su Merced fueron a la Casa de cabildo

La fecha de la traslación de Anserma se ha documentado en el año 1717. De ello tenemos un testigo que en ese entonces actuaba como Juez Privativo de Tierras, don Ignacio Fernández de Ventosa. 


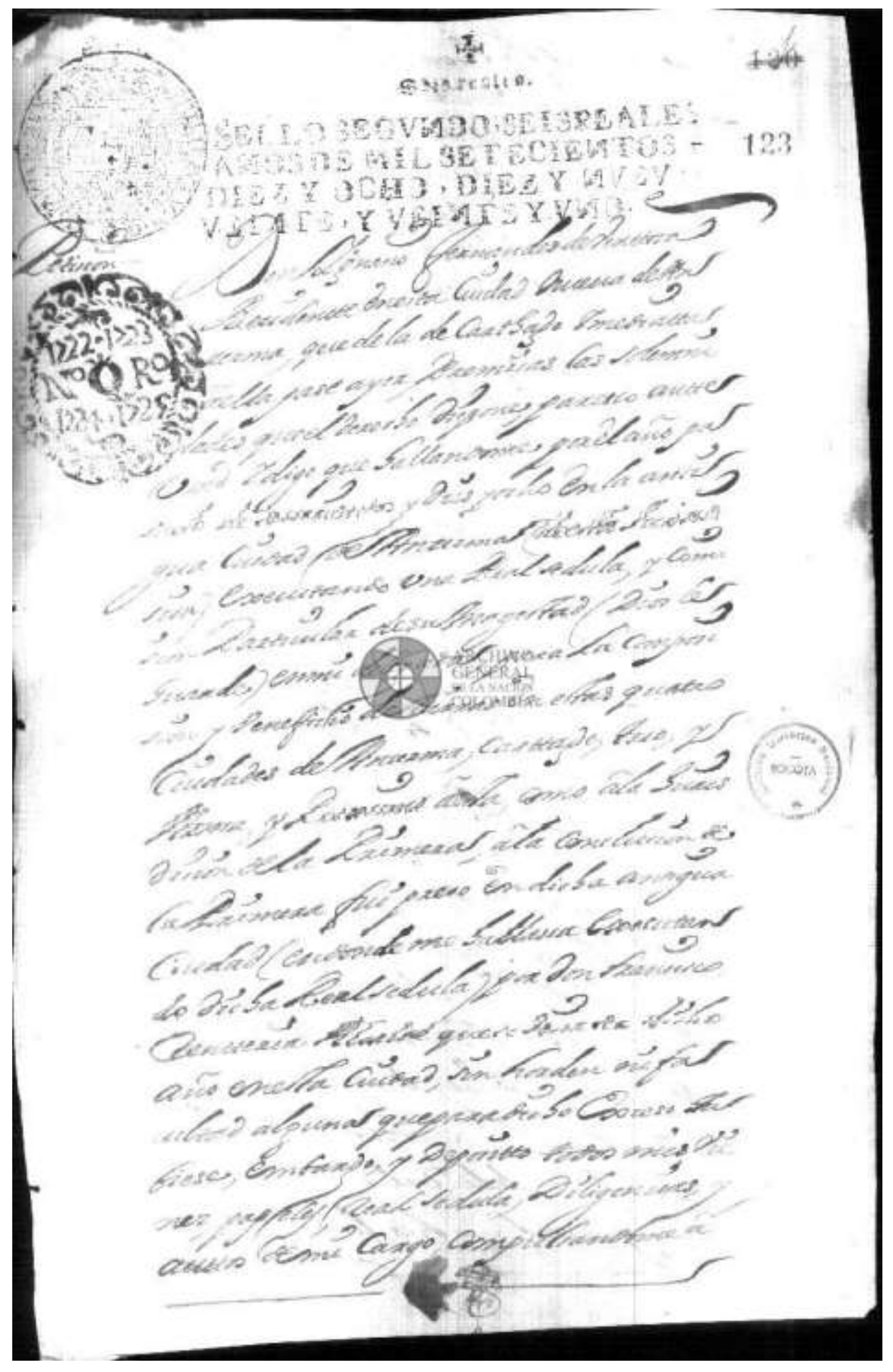

Figura 12. Composición de tierras las dos Ansermas, 1719

Fuente: Archivo General de la Nación (AGN), MISCELANEA: SC.39, 32, D.9, acceso el 15 de noviembre de 2019, Acceso el 15 de noviembre 2019. http://consulta.archivogeneral.gov.co/ConsultaWeb/imagenes.jsp?id=3061055\&idNodoImagen=1943837\&tot $\mathrm{al}=32 \&$ ini $=1 \&$ fin $=20$. 
1. Petición. Don Ignacio Fernández de Ventosa

2. residente en esta Ciudad Nueva de An-

3. serma, que de la de Cartago inmediata

4. a ella pasé ayer, premisas las solemni-

5. dades que el derecho dispone, parezco

6. ante vuestra Merced y digo que hallándome por el año pa-

7. sado de setecientos y diez y ocho en la Anti-

8. gua Ciudad de Anserma (de esta jurisdic-

9. ción) particular de Su Majestad (Dios le

10. guarde) / en mi delegada, para la composi-

11. ción y beneficio de tierras en estas cuatro

12. ciudades de Anserma, Cartago, Toro, y

13. Arma, y próximas a esta, como a la juris-

14. dicción de la primera, a la conclusión de

15. la primera fui preso en dicha Antigua

16. ciudad (en donde me hallaba ejecutan-

17. do dicha Real Cédula) por Don Francisco

18. Rentería Alcalde que se ejercía dicho

19. año en esta ciudad, sin orden ni fa-

20. cultad alguna que para dicho exceso tu-

21. viese, embargó, y depositó todos mis bie-

22. nes, papeles, Real Cédula, diligencias, y

23. autos de mi cargo, compulsándome a 


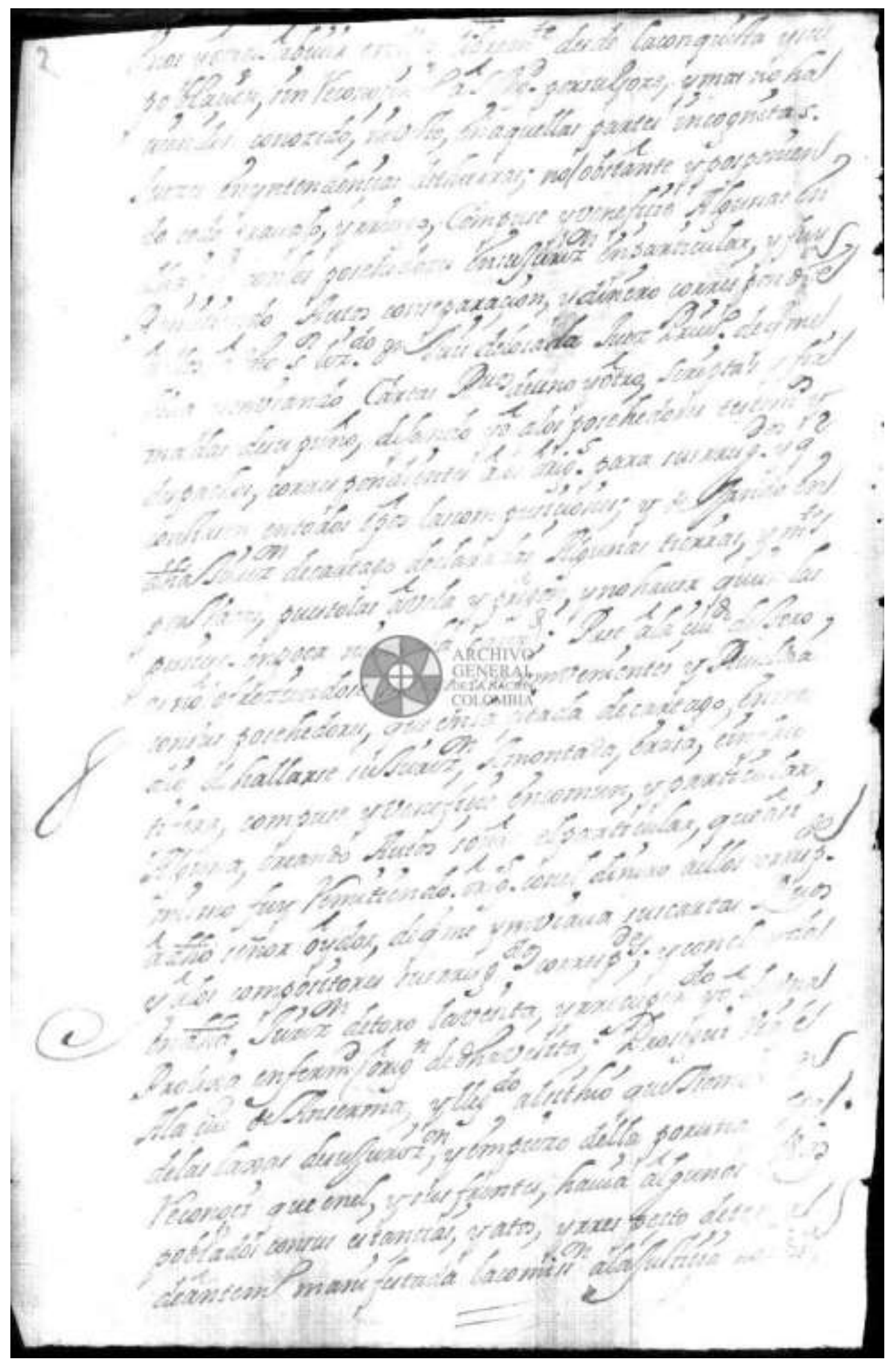

Figura 13. Composición de tierras las dos Ansermas, 1719

Fuente: Archivo General de la Nación (AGN), MISCELANEA: SC.39, 32, D.9. 
1. unos y otros a vivir en ellas libremente desde la conquista y su

2. población, sin reconocimiento a su Majestad por su goce, y mas no ha-

3. biendo conocido, ni visto, en aquellas partes incógnitas

4. Jueces en intendencias de tierras; no obstante y posponien-

5. do todo trabajo, y riesgo, compuse y beneficié algunas en

6. dicha ciudad con los poseedores en su jurisdicción en particular, y fui

7. remitiendo autos con separación y, dinero correspondiente

8. a ellos a dicho Señor Licenciado Don Luis de Lozada Juez Privativo de que me

9. iba enviando cartas recibos de uno y otro, escritas y fir-

10. madas de su puño, dejando yo a los poseedores testimonios y

11. despachos, correspondientes a los originales para sus resguardos y

12. que constasen en todos tiempos las composiciones; y dejando en

13. dicha jurisdicción de Cartago declaradas algunas tierras, y montes

14. por vacas, puéstolas a vela y pregón, y no haber quien las

15. pusiese, en poca ni mucha cantidad; pasé a la Ciudad de Toro,

16. y no ofreciéndose menos inconvenientes y rebeldía

17. con sus poseedores, que en la citada de Cartago, en me-

18. dio de hallarse su jurisdicción, amontada, crasa, e infruc-

19. tífera, compuse y beneficié en común, y particular

20. alguna, creando autos sobre el particular, que así

21. mismo fui remitiendo originales con el dinero a ellos correspondiente

22. a dicho Señor Oidor, de que me enviaba sus cartas recibos

23. y a los compositores sus resguardos correspondientes, y concluida

24. en dicha jurisdicción de Toro la visita, y recuperado yo de una

25. prolija enfermedad /origen de dicha visita; proseguí viaje

26. a la Ciudad de Anserma, y llegado al sitio que nombraban

27. de Las Lajas de su jurisdicción, y empiezo de ella por una parte

28. reconocí que en él, y sus frentes, había algunos ranchos

29. poblados con sus estancias, y hatos, y respecto deber por

30. de ante mí manifestada la comisión a la Justicia Ordinaria 


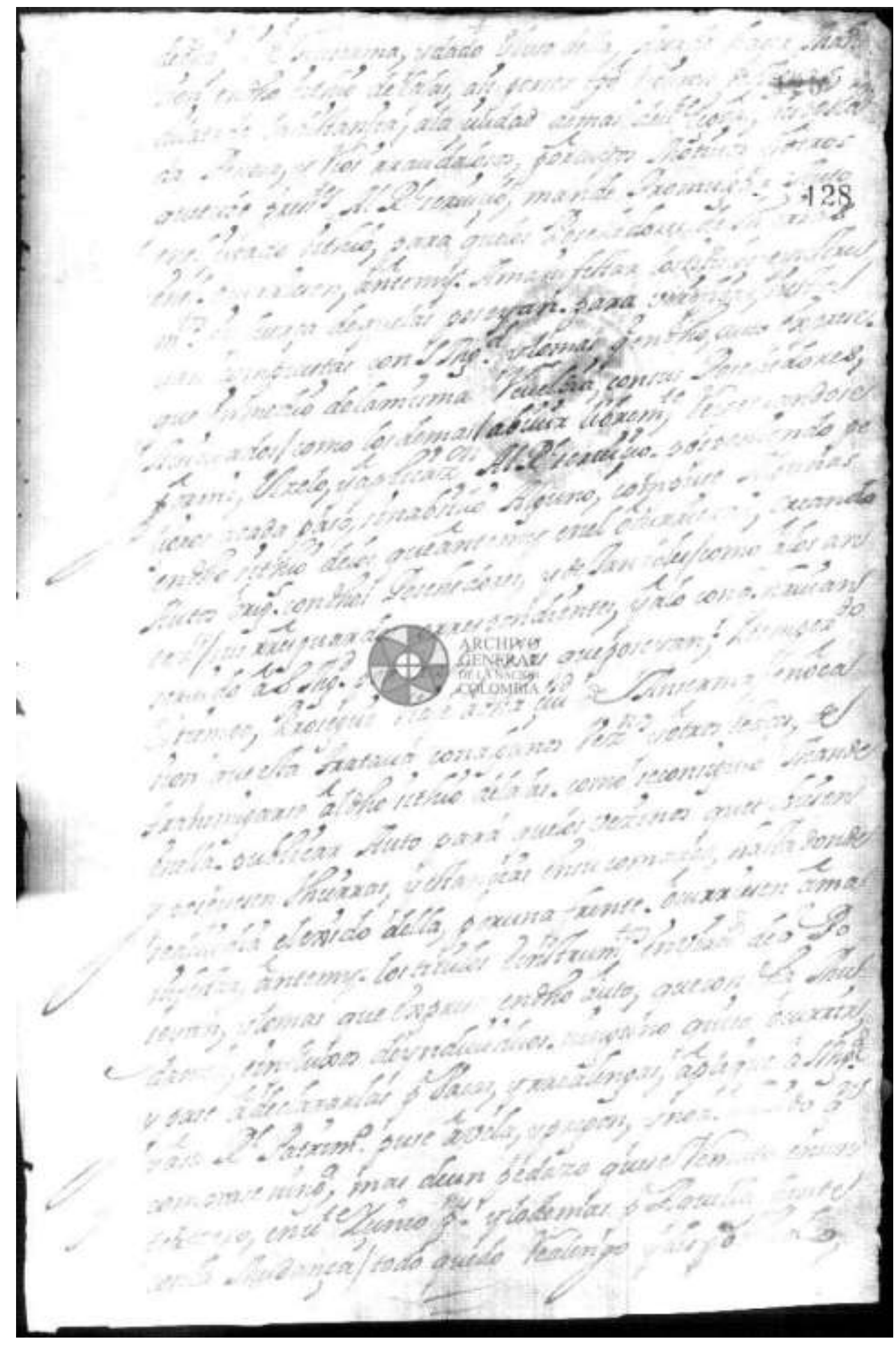

Figura 14. Composición de tierras las dos Ansermas, 1719

Fuente: Archivo General de la Nación (AGN), MISCELANEA: SC.39, 32, D.9 
1. de dicha, Ciudad de Anserma, y dado el uso de ella, acordé hacer man-

2. sión, en dicho sitio de Lajas, así por ser tiempo riguroso de lluvias

3. dilatada la distancia, a la ciudad de más de veinte leguas, despobla-

4. da, penosa, y ríos raudalosos, por cuyos motivos y otros

5. que tuve presentes, al Real servicio, mandé promulgar auto

6. en el citado sitio, para que los poseedores de tierras

7. en él ocurriesen, ante mí a manifestar los títulos e instru-

8. mentos en fuerza de que las poseían para verificar, si esta-

9. ban compuestas con su Majestad y lo más que en dicho, auto expresé

10. que en medio de la misma rebeldía, con sus poseedores,

11. habituados/ como los demás/ a vivir libremente, reiterándose

12. por mí, el celo, y aplicación al Real servicio posponiendo pe-

13. ligros a cada paso, sin auxilio alguno, compuse algunas

14. en dicho sitio de los que ante mí en él ocurrieron, creando

15. autos originales con dichos poseedores, y dejándoles /como a los an-

16. teriores/ sus resguardos correspondientes, y a lo con que habían

17. servido a su Majestad por razón de las que poseían; y sin perdida

18. de tiempo, proseguí viaje a dicha Ciudad de Anserma y en oca-

19. sión que esta trataba con algunos vecinos y otros reacces, de

20. transmigarse al dicho sitio de Lajas como se consiguió mandé

21. en ella publicar auto para que los vecinos que tuviesen

22. y poseyesen tierras, y estancias en su comarca, hasta donde

23. se dividía el ejido de ella, por una frente ocurriesen a ma-

24. nifestar, ante mí los títulos e instrumentos en virtud de cual po-

25. seían, y lo más que expresé en dicho auto, que con dicha mu-

26. danza, e influjos de individuos ninguno quiso ocurrir

27. y pasé a declararlas por vacas, y realengas, apliqué a su Majestad

28. y a su Real patrimonio puse a vela, y pregón, y no ha parecido quien

29. comprare ninguna, más de un pedazo que se remató en un

30. tercero, en veinte y cinco patacones y lo demás por aquella frente

31. /con la mudanza/ todo quedó realengo y despoblado.

Así las cosas, se da la traslación, al parecer más por intereses de tipo particular. Como dice el documento anterior, muchos lo hicieron por obligación, pues se mostraban inconformes; pero lo cierto es que la documentación que se encuentra a partir de la fecha se relaciona con la nueva población llamada La Ciudad de Señora Santa Ana de los Caballeros de Anserma, el sitio original queda como paso obligado hacia La Vega de Supía y El Valle del Cauca. Sin embargo, algunos pobladores permanecen en el lugar y la iglesia sigue siendo el eje de doctrina para las encomiendas con sus pueblos de indios. La tierra que no estaba en poder de los encomenderos quedó realenga y, como tal, aparecen sucesivos documentos donde se rematan muchas de ellas. En adelante el nombre de la primitiva población no desaparecerá y figurará en los mapas como Anserma Viejo.

No conozco aún un documento donde de manera oficial se haya pedido y autorizado el traslado de la población, creo que las traslaciones de Cartago y Anserma están muy relacionadas, ambas argumentaban la hostilidad de los indios, pero creo que están más condicionadas a intereses económicos particulares.

El aditamento de poder mudar las fundaciones iniciales a otro sitio mejor puede haber sido uno de los argumentos, más cuando las nuevas fundaciones se hacen dentro de áreas que pertenecían a las ciudades en los límites que les dieron desde que fueron creadas.

Hay un documento donde se conceptúa sobre la traslación y que apoya los argumentos anteriores. Se trata de otra visita fallida de un oficial real. Al parecer los vecinos que actuaban como cabildantes y funcionarios de su majestad crearon en esta región una red familiar 
extensa que dominaba los cargos principales y se negaban en repetidas ocasiones a rendir cuentas de sus desfalcos.

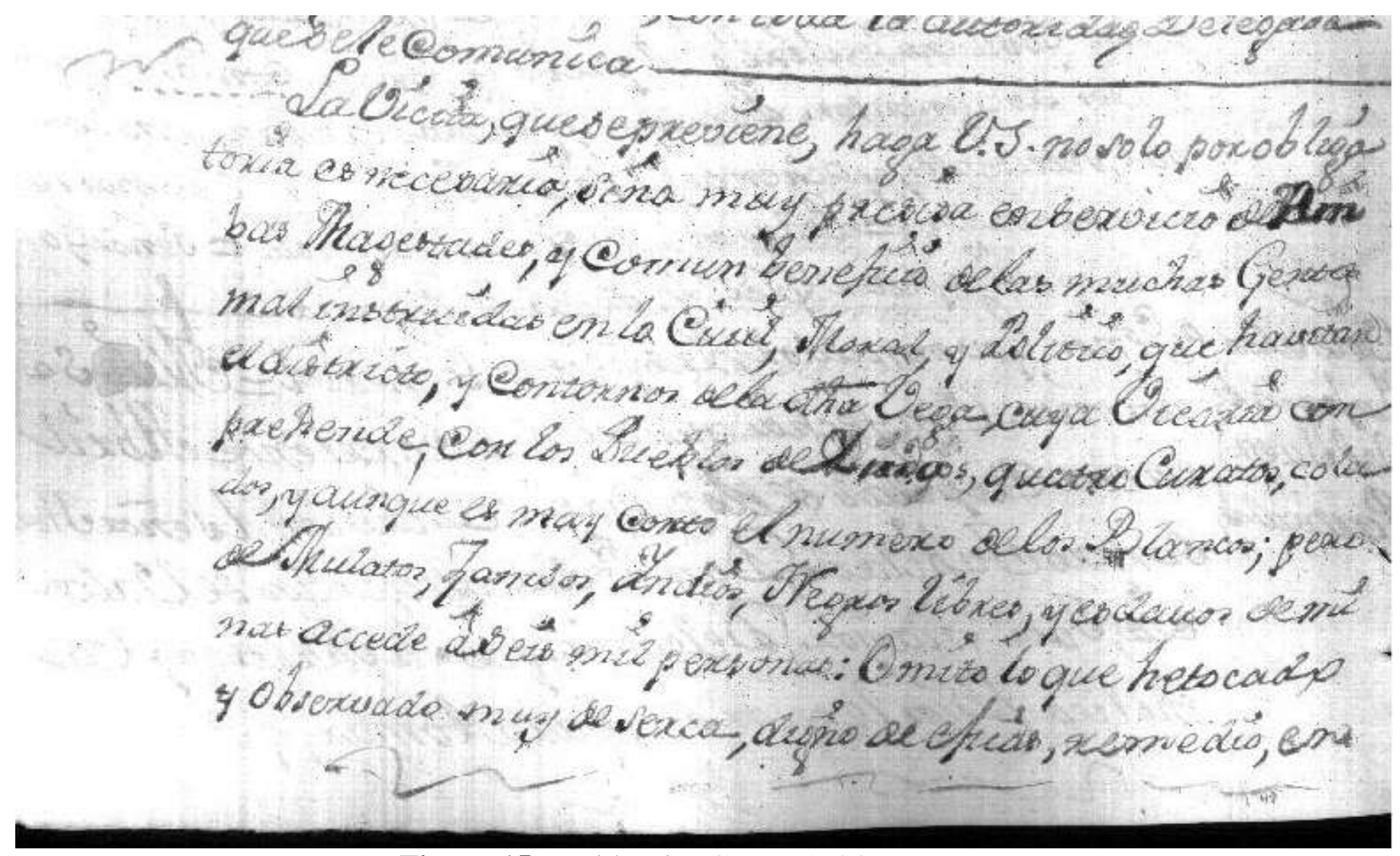

Figura 15. Residencias Cauca, 1784

Fuente: Archivo General de la Nación (AGN), RESI - CAUCA: SC. 54,61, D.11, acceso el 15 de noviembre de 2019. http://consulta.archivogeneral.gov.co/ConsultaWeb/imagenes.jsp?id=3134204\&idNodoImagen=1567717\& tot al=50\&ini $=1 \&$ fin $=20$

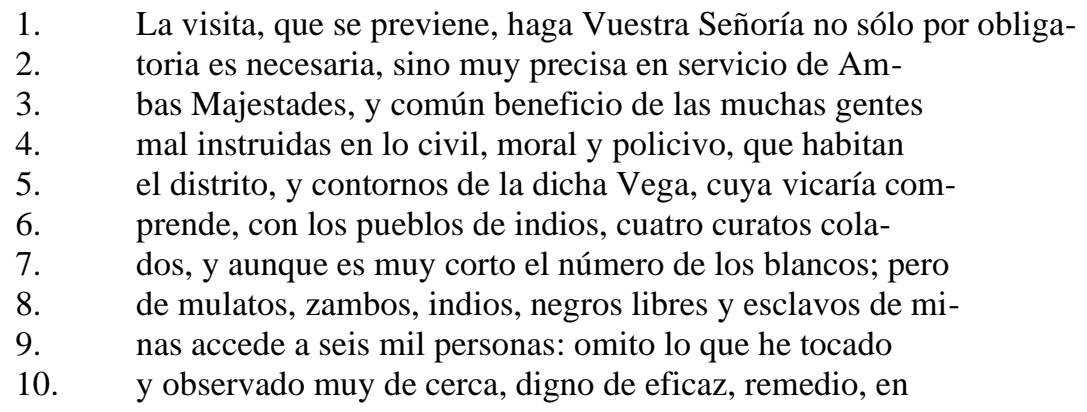




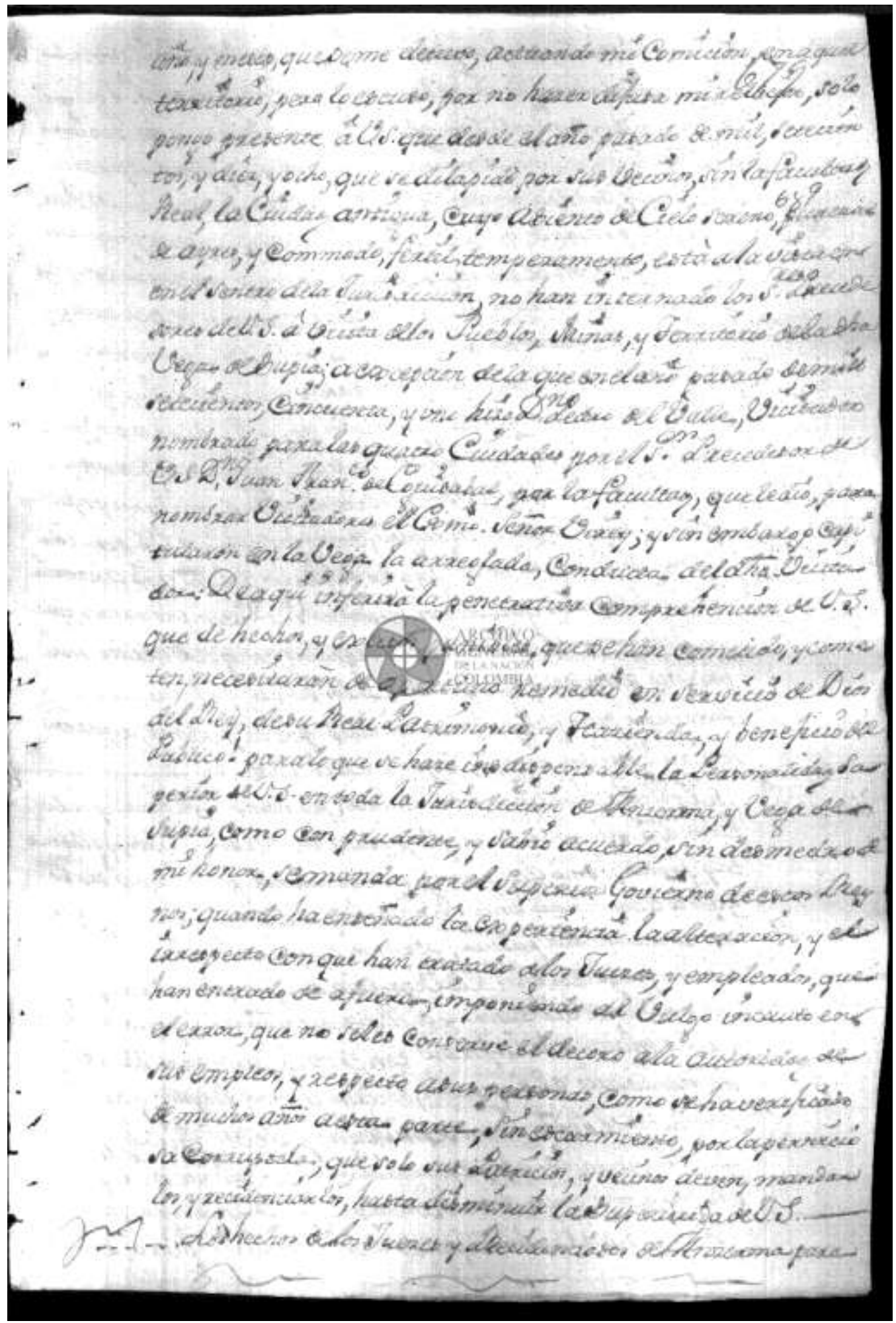

Figura 16. Residencias Cauca, 1784

Fuente: Archivo General de la Nación (AGN), RESI - CAUCA: SC. 54,61, D.11, acceso el 15 de noviembre de

2019 ,

http://consulta.archivogeneral.gov.co/ConsultaWeb/imagenes.jsp?id=3134204\&idNodoImagen=1567717\&tot $\mathrm{al}=50 \& \mathrm{ini}=1 \&$ fin $=20$ 
1. Año, y meses, que se me detuvo, actuando mi comisión en aquel

2. territorio, pero lo excuso, por no hacer difusa mi relación, solo

3. pongo presente a Vuestra Señoría que, desde el año pasado de mil, setecien-

4. tos, y diez, y ocho, que se dilapidó por sus vecinos, sin la facultad

5. Real, la Ciudad Antigua, cuyo asiento de cielo sereno, pureza

6. de aires, y cómodo, fértil temperamento, está a la vista en

7. el centro de la jurisdicción, no han internado los señores predece-

8. sores de Vuestra Señoría a visita de los pueblos, minas y territorio de la dicha

9. Vega de Supía, a excepción de la que en el año pasado de mil

10. setecientos, cincuenta y uno hizo Don Pedro del Valle, Visitador

11. nombrado para las cuatro ciudades por el Señor predecesor de

12. Vuestra Señoría

Para conocer un poco sobre cómo transcurrieron los primeros años de la nueva fundación pueden consultar en el Archivo General de Nación el documento 1726 - Causa de residencia a los Alcaldes Ordinarios de Santana de los Caballeros. Las dos Ansermas siguen figurando en los mapas, denotando su existencia paralela. 


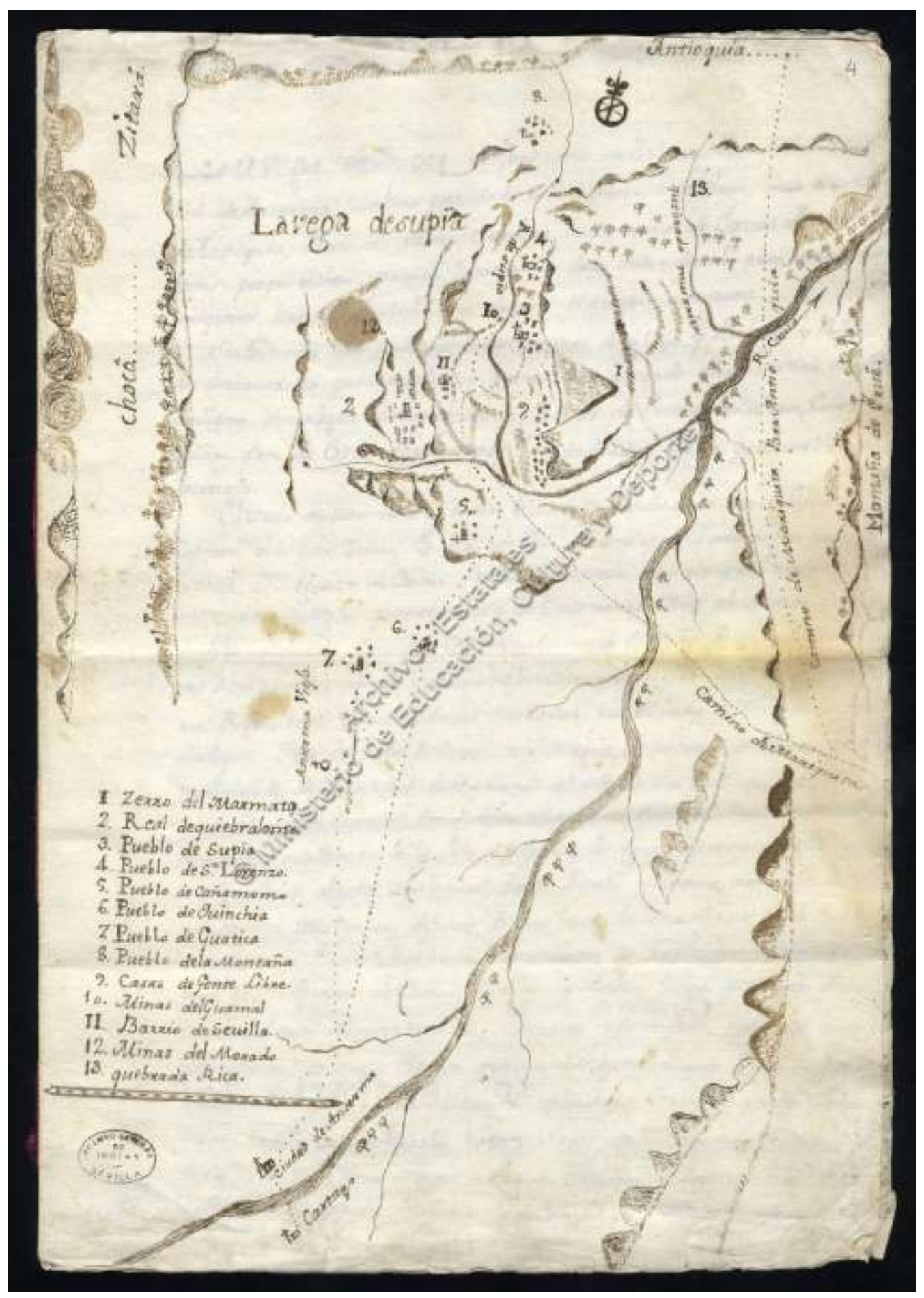

Figura 17. Mapa de La Vega de Supía, 1782

Fuente: Archivo General de Indias (AGI), España. MP-PANAMA,356 en "Mapa de la Vega de Supia, Gobierno de Popayán, jurisdicción de la ciudad de Ancerma, con el río Cauca, pueblos de Supia, San Lorenzo, Cañamomo, Quichia, Guatica, La Montaña y minas de Guamal y del Morado", Ministerio de Cultura y Deporte. Gobierno de España, acceso el 15 de noviembre de 2019, http://pares.mcu.es/ParesBusquedas20/catalogo/show/22433. 


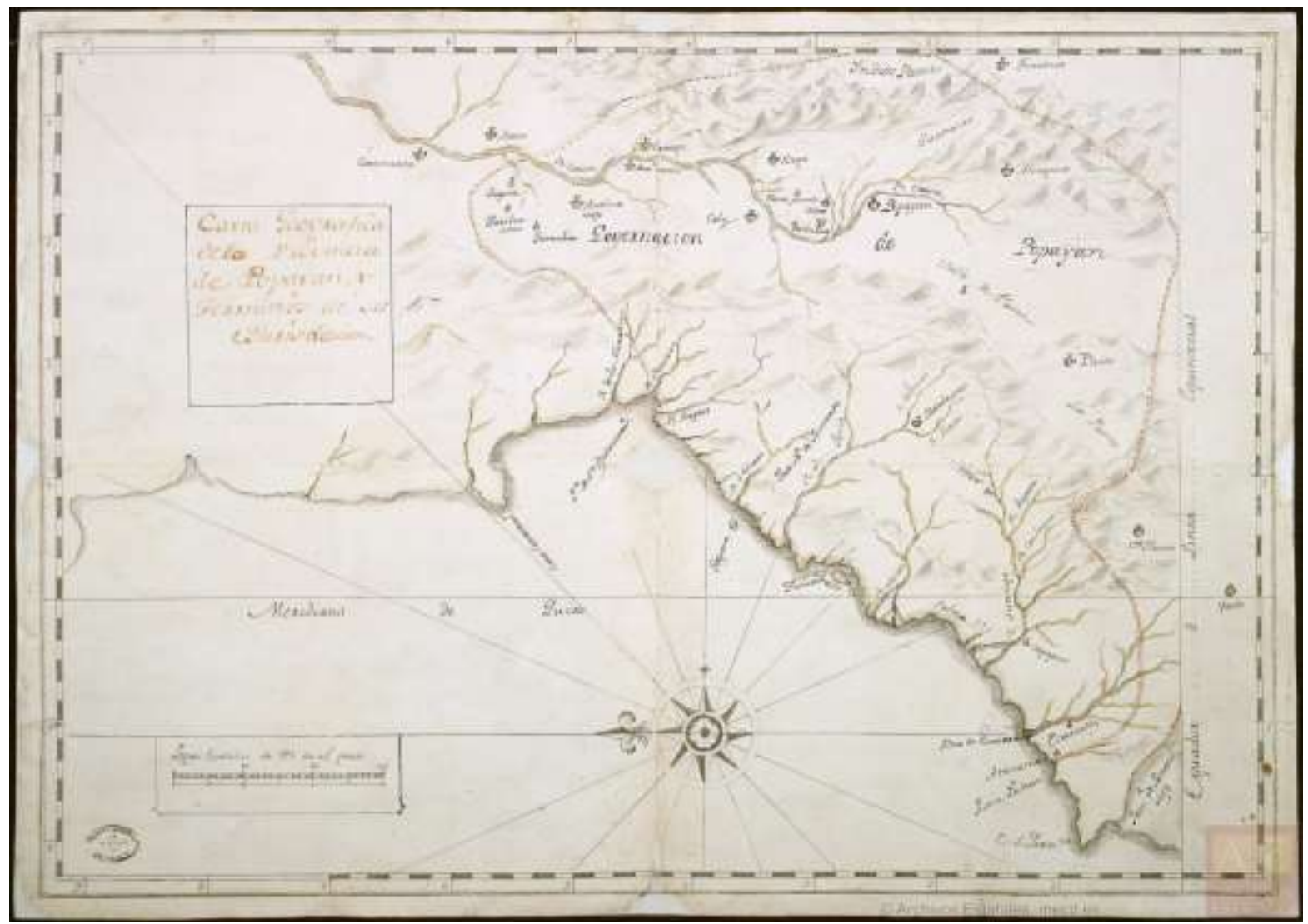

Figura 18. Provincia de Popayán, 1793

Fuente: Archivo General de Indias (AGI), España. MP-PANAMA,220 en "Carta Geográfica de la Provincia de Popayan y términos de su jurisdiccion", Ministerio de Cultura y Deporte. Gobierno de España, acceso el 15 de noviembre de 2019, http://pares.mcu.es/ParesBusquedas20/catalogo/description/22285. 


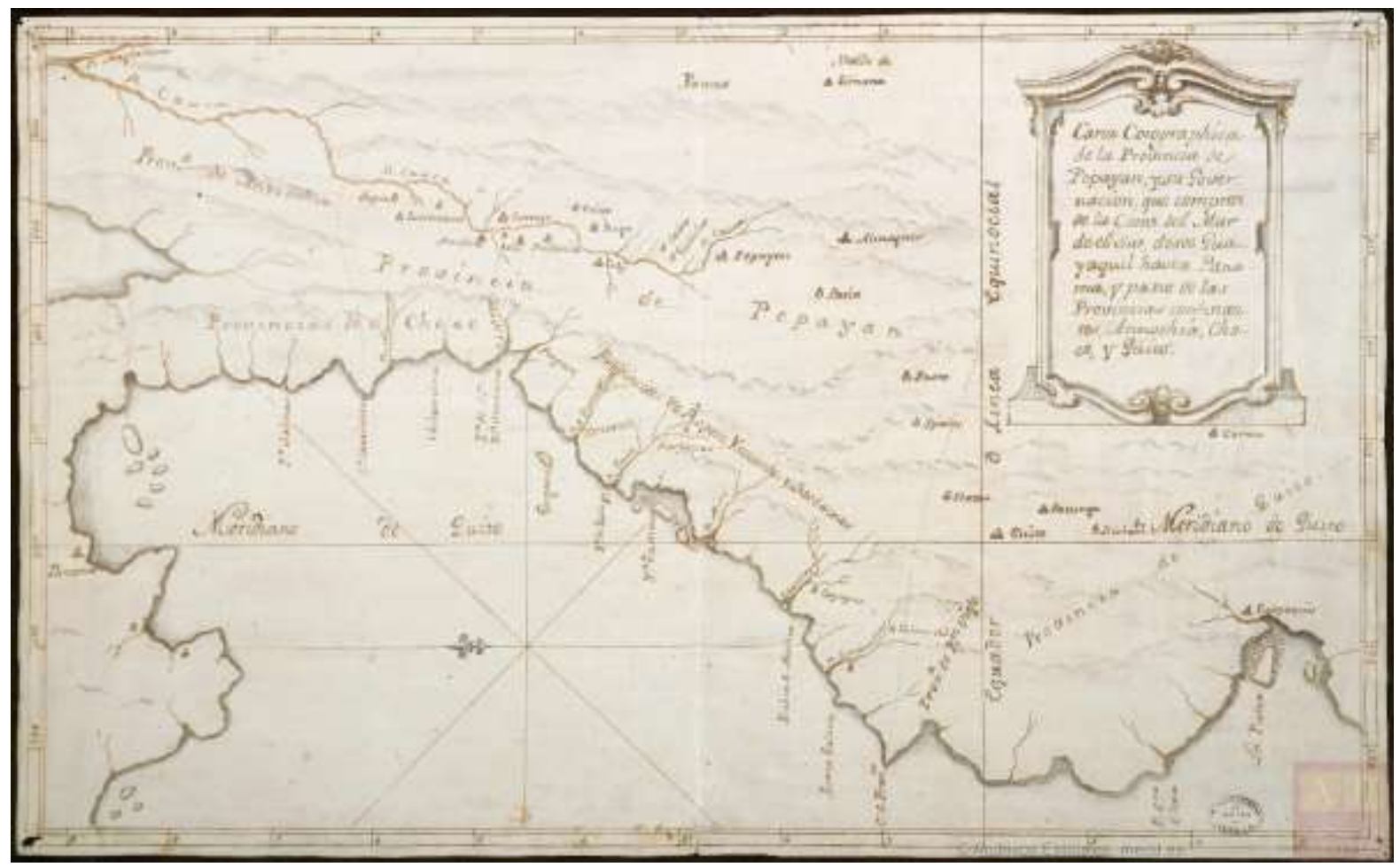

Figura 19. Provincia de Popayán, 1797

Fuente: Archivo General de Indias (AGI), España. MP-PANAMA,222 en "Carta Corográphica de la Provincia de Popayan, y su Governación, que comprende la Costa del Mar del Sur, desde Guayaquil hasta Panamá, y parte de las Provincias confinantes, Antiochia, Choco y Quito", Ministerio de Cultura y Deporte. Gobierno de España, acceso el 15 de noviembre de 2019, http://pares.mcu.es/ParesBusquedas20/catalogo/description/22287.

Finalmente, quedan dos documentos para demostrar que los vecindarios de las dos Ansermas legitimaron la posesión por separado de los terrenos aledaños a las poblaciones. Los de Anserma Viejo, por medio de una Cédula Real de lo que había quedado realengo después de la traslación, y los de Anserma Nuevo, por compra a un particular. 


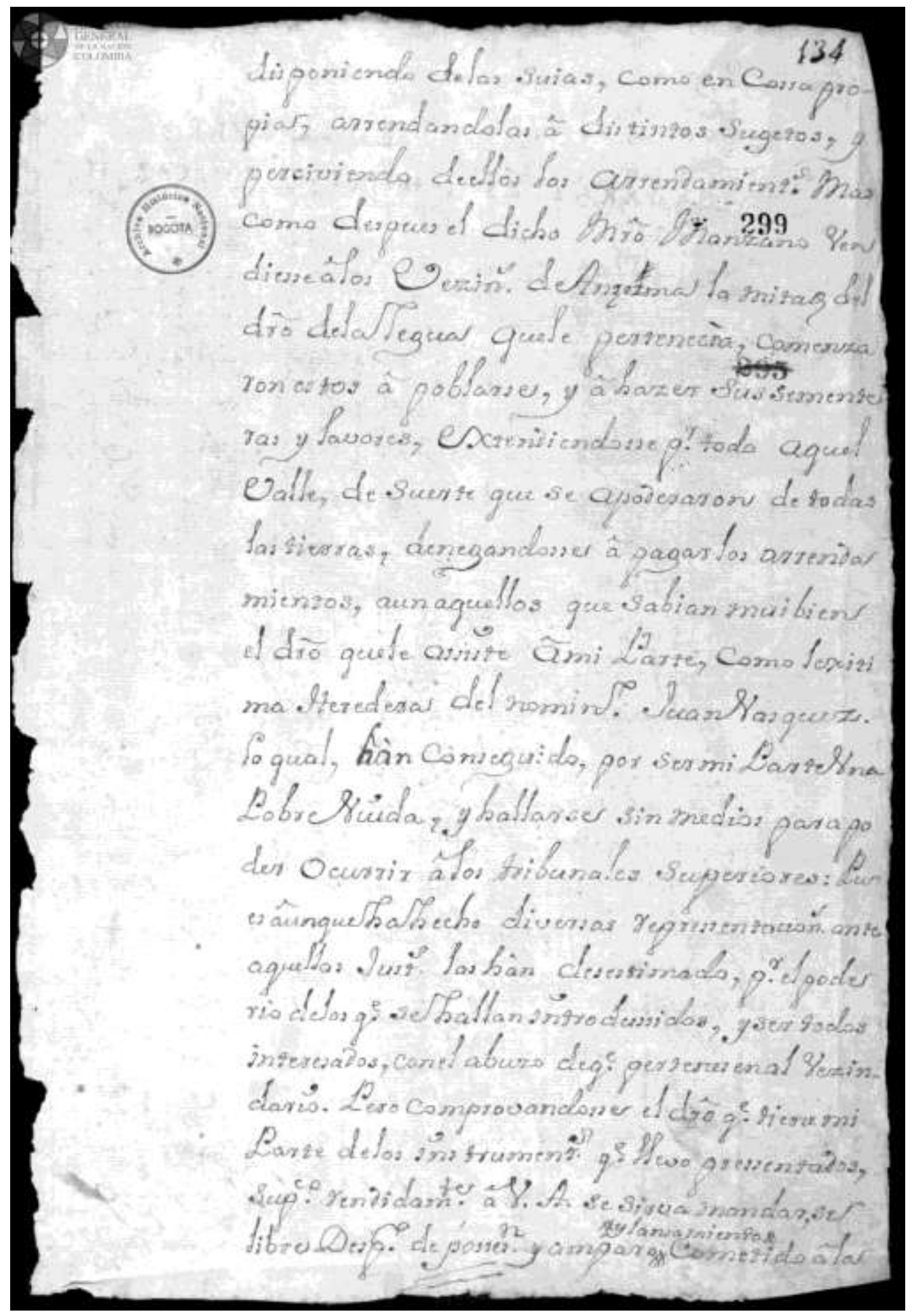

Figura 20. Tierras de vecinos de Anserma Nuevo, 1763

Fuente: Archivo General de la Nación (AGN), MISCELANEA: SC.39,48, D.9, acceso el 15 de noviembre de 2019 ,

http://consulta.archivogeneral.gov.co/ConsultaWeb/imagenes.jsp?id=3062735\&idNodoImagen=3062764\&tot $\mathrm{al}=10 \& \mathrm{ini}=1 \& \mathrm{fin}=10$ 
1. Disponiendo de las suyas, como en cosa pro-

2. pia, arrendándolas a distintos sujetos, $\mathrm{y}$

3. percibiendo de ellos los arrendamientos. Más

4. como después el dicho Maestro Manzano ven-

5. diese a los vecinos de Anserma la mitad del

6. derecho de la legua que le pertenecía, comenza-

7. ron estos a poblarse, y a hacer sus semente-

8. ras y labores, extendiéndose por todo aquel

9. valle, de suerte que se apoderaron de todas

10. las tierras, denegándose a pagar los arrenda-

11. mientos, aún aquellos que sabían muy bien

12. el derecho que le asiste a mi parte, como legíti-

13. ma heredera del nominado Juan Vásquez...... 


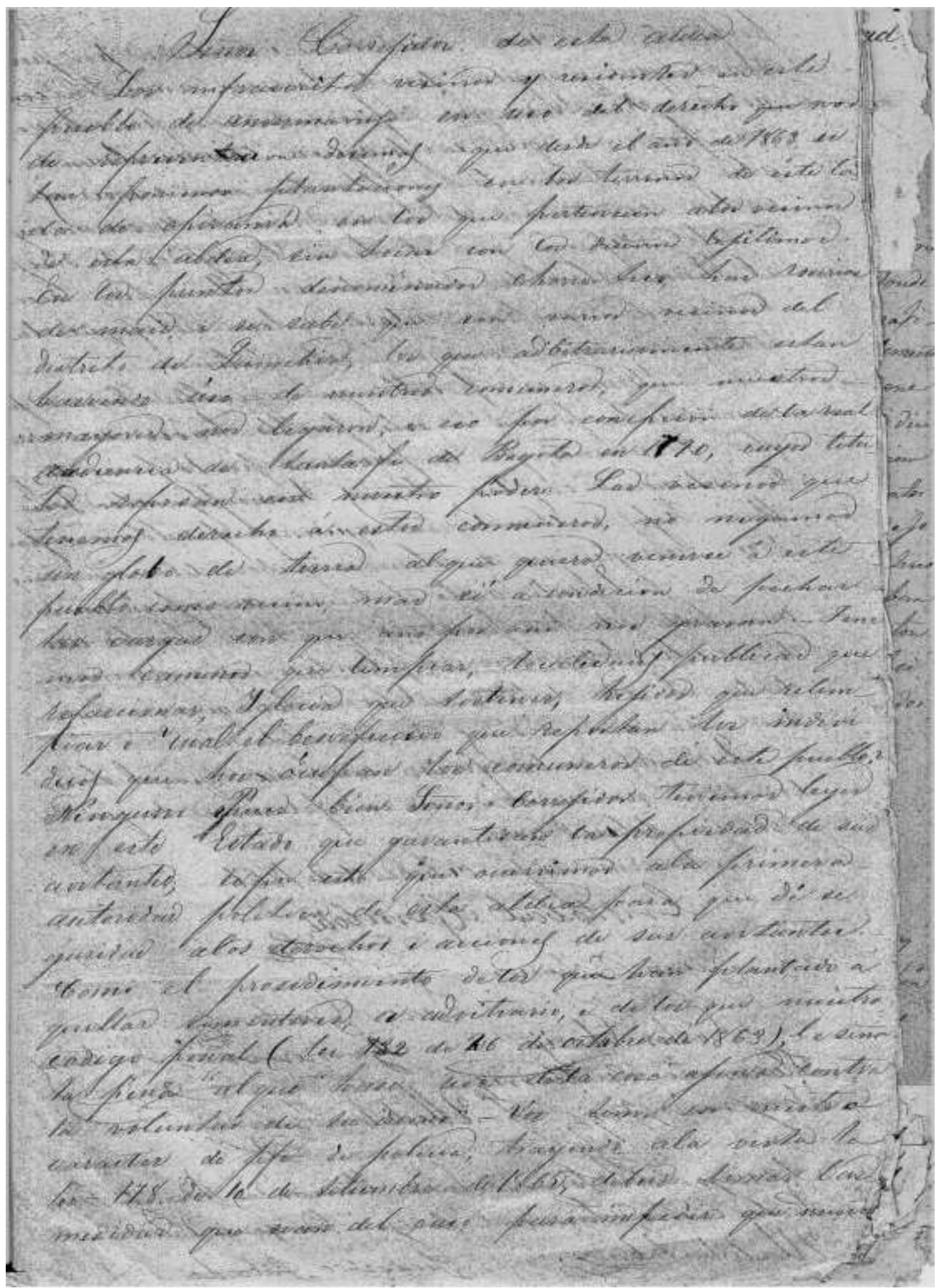

Figura 21. Títulos del vecindario de Anserma Viejo, 1790

Fuente: Archivo personal. "Paleografía", Juan Carlos Vallejo Velásquez, acceso 15 de noviembre de 2019, http://ansermalaantigua.blogspot.com/. 
1. Señor Corregidor de esta Aldea

2. Los infrascritos vecinos y residentes en este

3. Pueblo de Ansermaviejo en uso del derecho

4. de representación decimos: que desde el año de 1863 es-

5. tán poniendo plantaciones en los terrenos de este la-

6. do de Opiramá en los que pertenecen a los vecinos

7. de esta Aldea, sin tocar con los dueños legítimos.

8. En los puntos denominados Chorro Seco, hay rocerías

9. de maíz, y se sabe que son varios vecinos del

10. Distrito de Quinchía, los que arbitrariamente están

11. haciendo uso de nuestros comuneros, que nuestros

12. mayores nos legaron, y eso por concesión de la Real

13. Audiencia de Santafé de Bogotá en 1790, cuyos títu-

14. los reposan en nuestro poder. Los vecinos que

15. tenemos derecho a estos comuneros, no negamos

16. un globo de tierra al que quiera venirse a este

17. pueblo como vecino, más si a condición de pechar

18. las cargas con que año por año nos gravan. Tene-

19. mos caminos que limpiar, localidades públicas que

20. refaccionar, Iglesia que sostener, ejidos que relim-

21. piar y ¿Cuál el beneficio que reportan los indivi-

22. duos que hoy ocupan los comuneros de este pueblo?

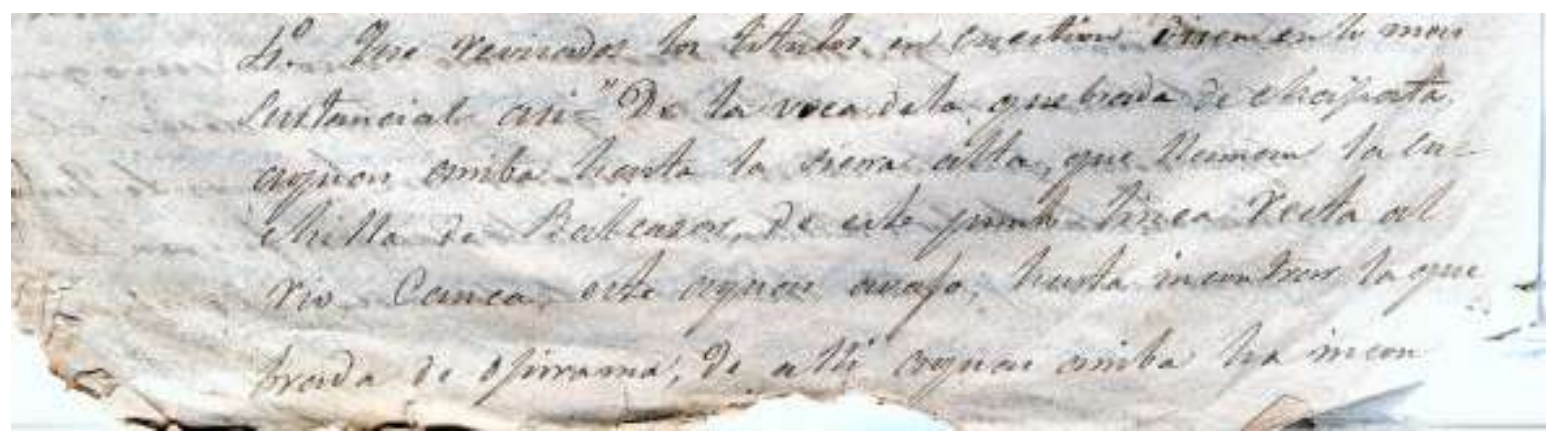

Figura 22. Títulos del vecindario de Anserma Viejo, 1790

Fuente: Archivo personal. "Paleografía", Juan Carlos Vallejo Velásquez, acceso 15 de noviembre de 2019, http://ansermalaantigua.blogspot.com/.

1. $\quad 4^{\circ}$ Que revisados los títulos en cuestión dicen en lo más

2. $\quad$ sustancial así: "De la boca de la Quebrada de Chápata

3. aguas arriba hasta la Sierra alta, que llaman la $\mathrm{Cu}$ -

4. chilla de Balcázar, de este punto línea recta al

5. Río Cauca, este aguas abajo, hasta encontrar la Que-

6. brada de Opirama, de allí aguas arriba a encon- 


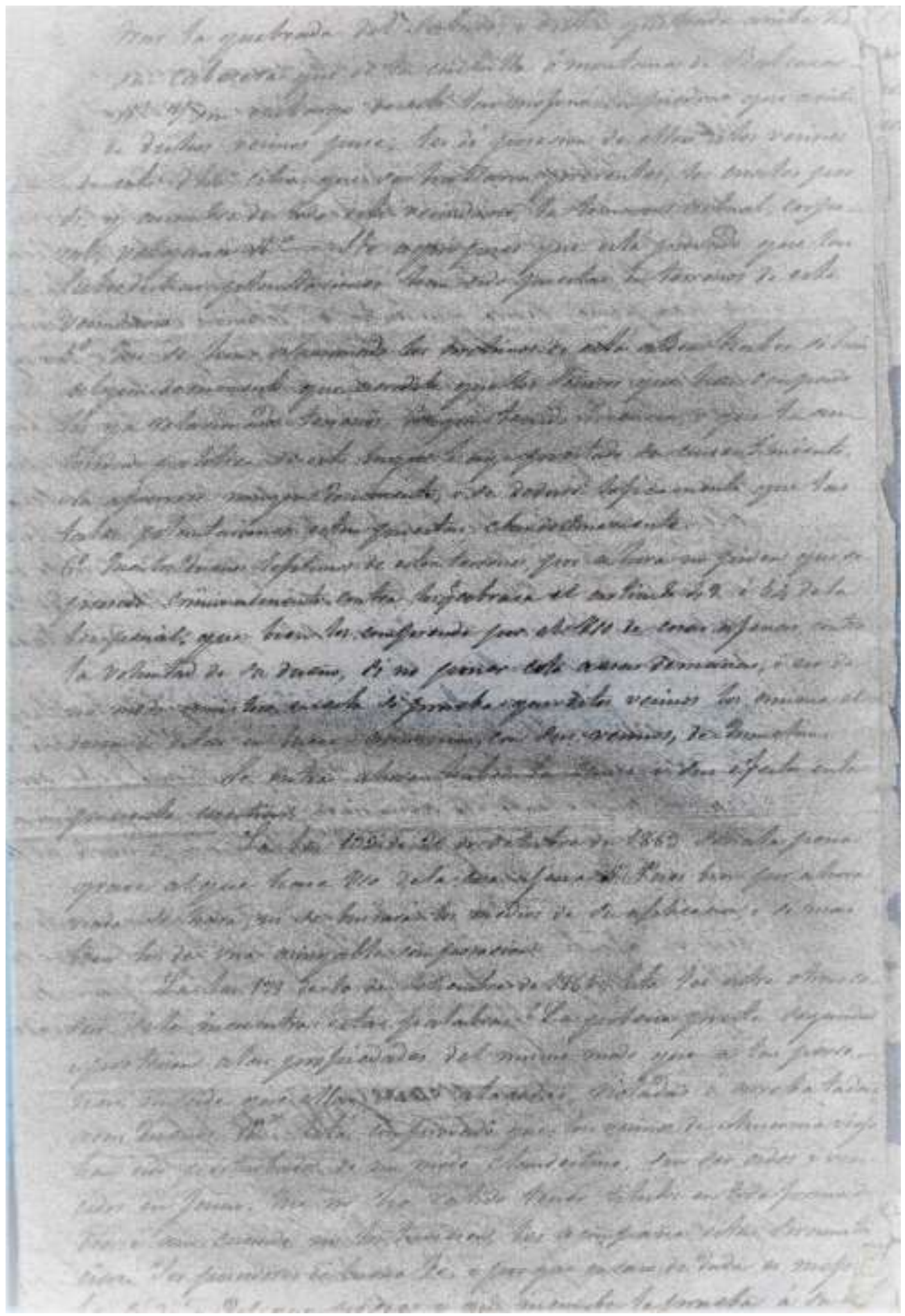

Figura 23. Títulos del vecindario de Anserma Viejo, 1790

Fuente: Archivo personal. "Paleografía", Juan Carlos Vallejo Velásquez, acceso 15 de noviembre de 2019, http://ansermalaantigua.blogspot.com/. 
1. trar la Quebrada del Salado, y dicha quebrada arriba a

2. su cabecera que es la Cuchilla o Montaña de Balcazar.

3. (etc.) Y sin embargo de esto las mojoné con piedras que a vista

4. de dichos vecinos puse; les di posesión de ellas a los vecinos

5. de este dicho Sitio, que se hallaron presentes, los cuales por

6. sí, y a nombre de todo este vecindario, la tomaron actual, corpo-

7. ral, velguasi (etc.)

\section{Epílogo}

La Ciudad de Anserma fue fundada el día de Nuestra Señora de Agosto de 1539 con el nombre de Santana, casi de inmediato se mudó al asiento de Anserma La Antigua y se le dio el nombre de San Juan. Sebastián de Belalcázar la nomina como Anserma y de paso sacrifica a Jorge Robledo por querer usurparle parte de su gobernación. Por intereses particulares se traslada a Las Lajas territorio de su jurisdicción en 1717, desde donde se siguió ejerciendo la autoridad política para toda la región. Anserma Viejo siguió existiendo y se nutrió del mestizaje, de los resguardos indígenas creados y de las oleadas colonizadoras de Antioquia para seguir su camino en la historia.

Ambas ciudades ejercieron dominio y encontraron el camino del desarrollo de una manera paralela y compleja, por eso se merecen el título de Ciudades Hermanas.

\section{Recomendaciones}

1. Participar en los escenarios ciudadanos para que se creen las dependencias del Centro de Historia de Anserma La Antigua, anexos al "Centro Cultural Ocuzca", que se proyecta construir.

2. Crear un grupo voluntario que administre y difunda la información procedente de los archivos físicos existentes, los digitalizados en archivos nacionales e internacionales y los particulares que se donen al centro documental.

3. Educar a los niños y jóvenes de la región sobre la importancia de conocer sus orígenes e invitarlos a participar de las actividades que se promocionen en el Centro de Historia.

4. Incorporar el Centro de Historia a las rutas del Paisaje Cultural Cafetero para su difusión y oferta a la investigación.

5. Difundir de manera permanente, a través de eventos, la producción documental, fotográfica, fílmica y de piezas arqueológicas que den cuenta de la riqueza cultural e histórica de la ciudad.

6. Extender redes de cooperación con los municipios hermanos e hijos de la Anserma histórica, para crear identidad y sentido de difusión de nuestras raíces y proyección futura.

7. Establecer conexiones con las universidades que tengan dentro de su misionalidad el estudio de la historia regional.

8. Abrir la oportunidad de crear paquetes turísticos dentro de la declaratoria de Paisaje Cultural Cafetero, que incluyan también caminatas y arrierías por las antiguas vías de la conquista y colonización de la ciudad histórica.

9. Los demás que sean necesarios, como producto de la dinámica que adquiera la concientización ciudadana que valore sus orígenes. 


\section{Referencias}

Archivo General de la Nación. Acceso el 15 de noviembre de 2019. http://www.archivogeneral.gov.co

. Popayán, Sección Mapas y Planos, Mapoteca SMP.4. Archivo General de la Nación (AGN), Popayán, Sección Mapas y Planos, Mapoteca SMP.4. Acceso el 15 de noviembre de 2019.

http://consulta.archivogeneral.gov.co/ConsultaWeb/imagenes.jsp?id=3255709\&idN odoImagen $=3255710 \&$ total $=1 \&$ ini $=1 \&$ fin $=1$

Historia Civil: SC.29, 1, D.14. Archivo General de la Nación (AGN), Historia Civil: SC.29, 1, D.14. Acceso el 15 de noviembre de 2019. http://consulta.archivogeneral.gov.co/ConsultaWeb/imagenes.jsp?id=3052699\&idN odoImagen $=2703593 \&$ total $=618 \&$ ini $=1 \&$ fin $=20$

MISCELANEA: SC.39, 32, D.9. Acceso el 15 de noviembre de 2019. http://consulta.archivogeneral.gov.co/ConsultaWeb/imagenes.jsp?id=3061055\&idN odoImagen $=1943837 \&$ total $=32 \&$ ini $=1 \&$ fin $=20$

RESI - CAUCA: SC. 54,61, D.11. Acceso el 15 de noviembre de 2019. http://consulta.archivogeneral.gov.co/ConsultaWeb/imagenes.jsp?id=3134204\&idN odoImagen $=1567717 \&$ total $=50 \&$ ini $=1 \&$ fin $=20$

- MISCELANEA: SC.39,48, D.9. acceso el 15 de noviembre de 2019 http://consulta.archivogeneral.gov.co/ConsultaWeb/imagenes.jsp?id=3062735\&idN odoImagen $=3062764 \&$ total $=10 \&$ ini $=1 \&$ fin $=10$

Ministerio de Cultura y Deporte. Gobierno de España. "Relación del viaje de Jorge Robledo a Quimbaya, Antioquia, etc.”. Acceso el 15 de noviembre de 2019. http://pares.mcu.es/ParesBusquedas20/catalogo/show/122042

. "Viaje del capitán Jorge Robledo: Ancerma, Quimbaya y Cartago". Gobierno de España. Acceso el 15 de noviembre de 2019. http://pares.mcu.es/ParesBusquedas20/catalogo/show/125291

. "Informaciones de Sebastián de Belalcázar". Acceso el 15 de noviembre de 2019. http://pares.mcu.es/ParesBusquedas20/catalogo/description/393190?nm

. "Mapa o descriçión de la Provincia del Chocó". Acceso el 15 de noviembre de 2019. http://pares.mcu.es/ParesBusquedas20/catalogo/description/22401

- "Mapa de la provincia del Chocó". Acceso el 15 de noviembre de 2019. http://pares.mcu.es/ParesBusquedas20/catalogo/description/22061. 
- "Mapa de la Vega de Supia, Gobierno de Popayán, jurisdicción de la ciudad de Ancerma, con el río Cauca, pueblos de Supia, San Lorenzo, Cañamomo, Quichia, Guatica, La Montaña y minas de Guamal y del Morado". Acceso el 15 de noviembre de 2019. http://pares.mcu.es/ParesBusquedas20/catalogo/show/22433

. "Carta Geográfica de la Provincia de Popayan y términos de su jurisdiccion". Acceso $\begin{array}{lllll}\text { el } & 15 & \text { de } & \text { noviembre }\end{array}$ http://pares.mcu.es/ParesBusquedas20/catalogo/description/22285

. "Carta Corográphica de la Provincia de Popayan, y su Governación, que comprende la Costa del Mar del Sur, desde Guayaquil hasta Panamá, y parte de las Provincias confinantes, Antiochia, Choco y Quito". Acceso el 15 de noviembre de 2019. http://pares.mcu.es/ParesBusquedas20/catalogo/description/22287

Vallejo Velásquez Juan Carlos. "Paleografía". Acceso 15 de noviembre de 2019. http://ansermalaantigua.blogspot.com/ 